\title{
47. CORRELATIONS OF THE NEOGENE FORMATIONS OF THE FLORENCE RISE AND OF NORTHERN CYPRUS: PALEOGEOGRAPHIC AND STRUCTURAL IMPLICATIONS
}

\author{
François Baroz, ${ }^{1}$ Daniel Bernoulli, ${ }^{2}$ Bernard Biju-Duval, ${ }^{3}$ Germaine Bizon, ${ }^{4}$ Jean-Jacques Bizon, ${ }^{4}$ and Jean \\ Letouzey, ${ }^{3}$
}

\section{REGIONAL FRAMEWORK OF THE NORTH EASTERN MEDITERRANEAN}

The Florence Rise, on which Holes 375 and 376 were drilled is an arcuate submarine ridge which runs from the Anaximander Mountains in the west to the island of Cyprus to the east (Figure 1). It separates the Antalya deep basin to the north from the Herodotus Abyssal Plain and the Nile Cone to the south: The ridge comes up to a depth of about 2000 meters; its structure has been investigated only recently during a IFP-CNEXO oceanographic cruise using multi-channel reflection seismics.

The Florence Rise is a very important tectonic feature along which the extremely thick Tertiary sequence of the Antalya Basin thins and the thick upper Miocene salt layer pinches out. The rise is part of a larger arcuate belt, the Cyprus Arc, which extends from the Levantine coast through the Troodos Mountains of southern Cyprus and the Florence Rise to the Anaximander Mountains south of Turkey. The front of the arc corresponds to the southern boundary of the Turkish plate of McKenzie (1972); the arc itself is the result of several superimposed tectonic phases of Late Cretaceous to Pliocene Quaternary age.

The entire region to the north of the Cyprus Arc forms an arcuate system which also results from compressive late Neogene movements (Biju-Duval et al., this volume). The following elements can be distinguished: The Minis-Pentadaktylos belt: the upthrust of Misis (Schmidt, 1961) can be followed into the steep thrust zones of the Pentadaktylos (Kyrenia) Range of northern Cyprus (Beltrandi, 1975; Biju-Duval, 1974; Mulder, 1973); farther west it is less obvious in the offshore Antalya Basin, but it is clearly recognized again in the Gebiz Mountains of southern Turkey (Blumenthal, 1963).

In the Misis area, the thrust is of late Miocene to Pleistocene age; it can easily be followed towards the north into the region of Andirin where it passes into

\footnotetext{
${ }^{1}$ Geological Institute of the University, Nancy, France.

${ }^{2}$ Geological Institute of the University, Basel, Switzerland.

${ }^{3}$ Institut Français du Pétrole, Rueil-Malmaison, France

4 Bureau d'Etudes Industrielles et de Coopération de I'I.F.P., Rueil-Malmaison, France
}

the broad Elazig-Maden-Bitlis overthrust of late Miocene to Pliocene age (Biju-Duval, 1974). Several reverse faults can be recognized, but the angle of thrusting is not well defined. The overthrusted sequence is composed of flysch sediments which include large exotic masses (Schmidt, 1961; Schiettecatte, 1971) which imply important tectonic movements during flysch sedimentation. These flysch sequences, generally attributed to the Oligocene-Miocene, were recently dated as Burdigalian to Serravallian (BijuDuval et al., 1974). The tectonic emplacement of this sequence during the late Miocene is in good agreement with the pinch-out of the upper Miocene salt layer of the Adana Basin along the flank of the structure.

Offshore, the different reverse faults can be traced to Cyprus and the structure appears to correspond to an upper Miocene high (pinch-out of the salt layer and of part of the Tortonian). We cannot determine whether exotic masses occur in the deeper layers as known onland from the seismic records. The angle of thrust seems to be low.

The Kyrenia or Pentadaktylos Range (Baroz, 1974) is a very narrow structure, upthrusted onto the Mesaoria Basin which in turn has been subjected to reverse faulting. The thrusts were active in post-late Miocene times as the Mediterranean evaporites were affected by the tectonic movements; in places they can be dated as early Pliocene by the Nicosia Formation unconformably overlying a reverse fault (Baroz, 1977). The general structure is complicated. The range is superimposed on older structures of late Eocene age as demonstrated by breccia formations (Baroz, 1970) and numerous olistoliths and olistostromes in the Eocene sediments (Kluyver, 1960; Biju-Duval et al., 1974), and the central area of the range might have been elevated since late Eocene times (Baroz, 1977). During this time important tectonic movements and emplacement of thrust nappes occurred in southern Turkey (Taurus).

Westward, in the deep Antalya Basin, post-evaporite structures are less evident but reverse faulting occurs below the very thick salt deposits (Figure 2).

Near the Gebiz Mountains which cut the onshore Antalya Basin into two parts, upper Miocene and flatlying lower Pliocene deposits (Ozer et al., 1975; Bizon et al., 1974) unconformably overlie tectonized sequences. Near Beskonak, reverse faults have brought 


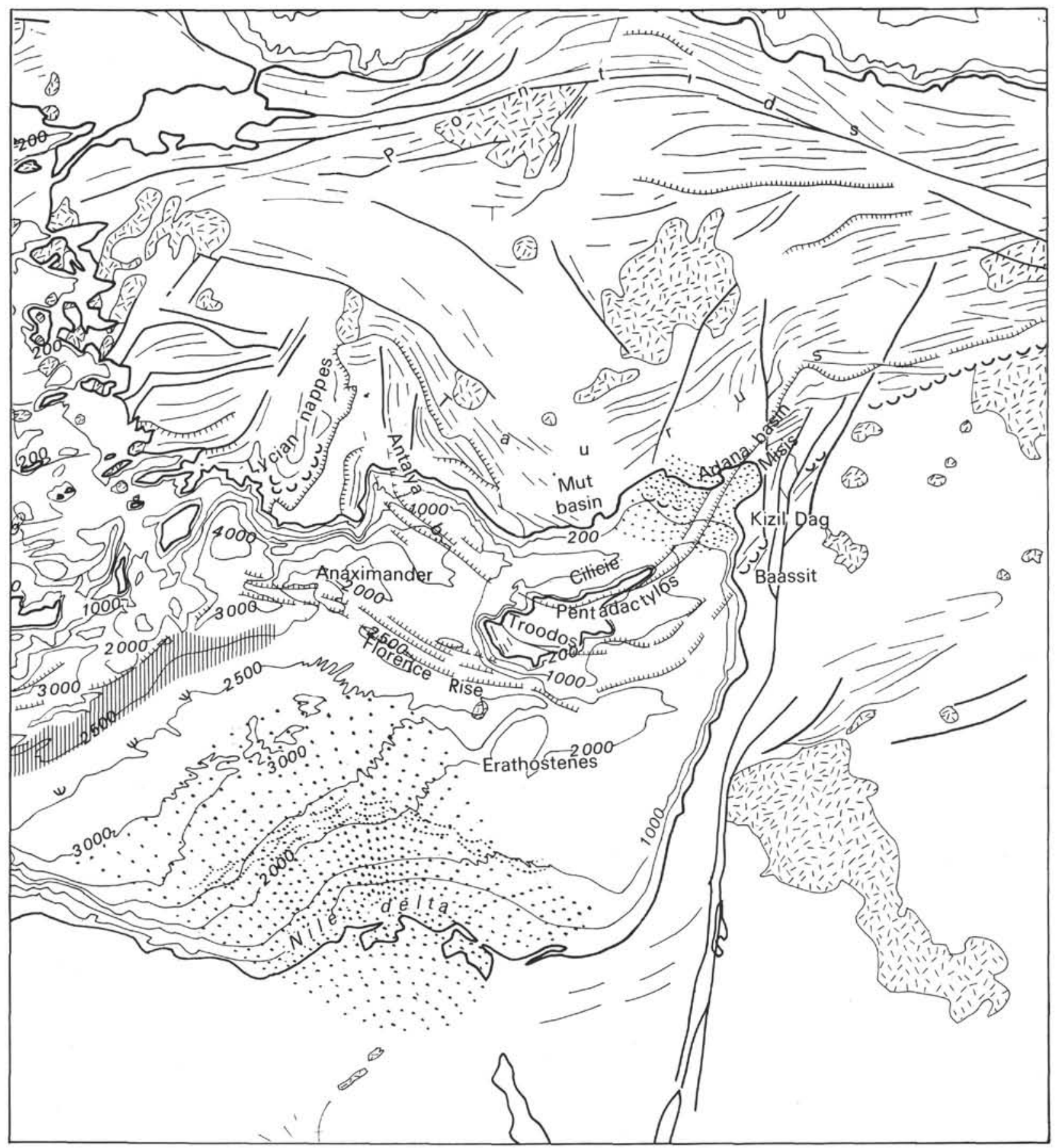

Figure 1. Structural map of the Eastern Mediterranean (from Biju-Duval et al. this volume, fig. 1). Florence Rise, with reverse faults, appears as a part of the Cyprus arc extending from Levantine coast (Baassit, Kizil Dag) to Anaximander Seamount. The Mediterranean ridge (vertical hachures) constitutes the front of the westward extent of the Alpine belt. Dots = main deltas (Nile, Ceyhan, Seyhan); broken short dashes = volcanism; bathymetry is in meters.

the Mesozoic on top of the Burdigalian, and Tortonian conglomerates are folded near Gebiz.

Neogene Basins: South of this general trend there is a complicated sequence of Neogene Basins (Iskenderun, North Levantine, Mesaoria, and deep Antalya basins) separated by onshore (Kizil Dag Massif, Trulli Inlier, Troodos-Kelaki Massif) as well as offshore highs (elevation of the acoustic basement).
Towards the south these basins are limited by the Cyprus Arc.

Onshore, the basement is disrupted by reverse faults. Different phases of thrusting are distinguished: north of the Troodos, the Ovgos and Kythrea faults were active during the Neogene (Aubert et Baroz, 1974); south of the Troodos, overturned sequences of Eocene age are present and small reverse faults occur in the upper 

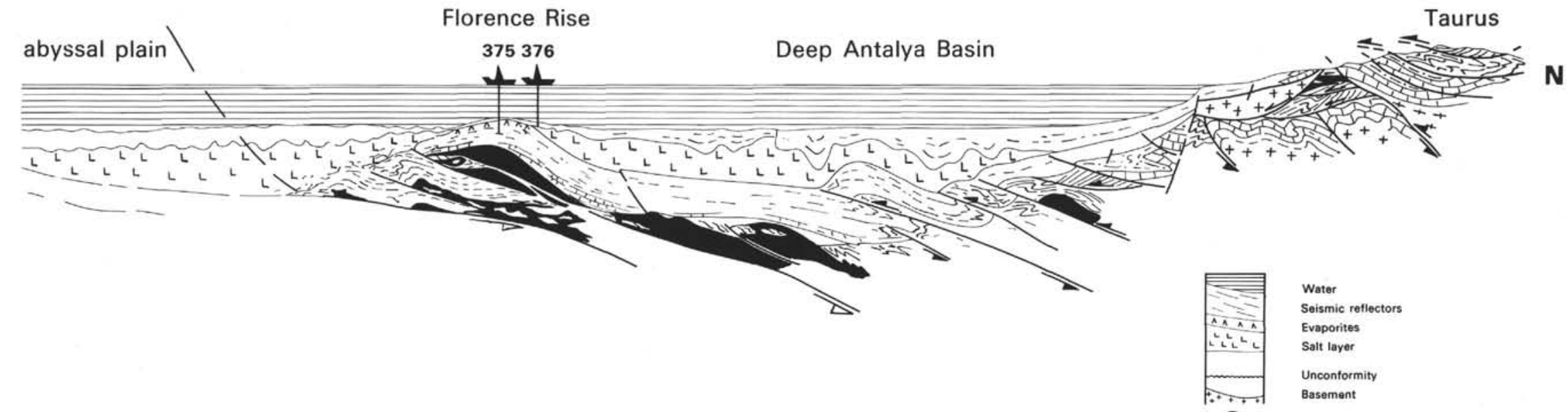

20 Main volcanoes

iो Magmatism

- Ophiolites :

Melanges

Orogenic belt

Main overthrusts

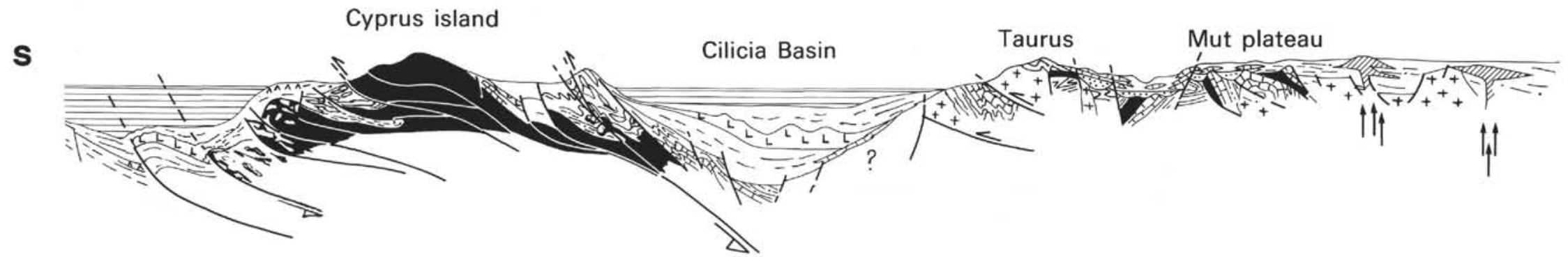

Figure 2. Interpretative geological cross-sections through the Cyprus arc (from Biju-Duval et al., this volume, fig. 10). Upper section: Florence Rise and Antalya Basin; Lower section: Cyprus and Cilicia Basin. Ophiolites and tectonic melanges of Cretaceous age in black. 
Miocene series (Koronia Limestone). Finally, late Cretaceous nappes are well known to occur in Turkey (Rigo de Righi and Cortesini, 1964; Sungurlu, 1974). In front of them, broad gravity nappes extend southwards onto the Arabic platform. They include Mesozoic pelagic and platform facies and ophiolites. Recently, on the basis of both onshore data and marine seismic data the extent of this general structural setting has been traced to Cyprus (Biju-Duval et al., 1977), where the Troodos ophiolites and the Mamonia nappes, which are very similar to the Kizil Dag and the Bassit nappes of the Levantine coast, are interpreted as a part of the Late Cretaceous orogene. The Troodos ophiolites, just as all the other ophiolitic sequences in the Mediterranean area, are obviously allochthonous.

Occurrences of ophiolites along the Cyprus Arc have previously been interpreted as relics of a Mesozoic oceanic basin originally situated south of the Taurus (Pamphylian Basin, Dumont et al., 1972; Monod et al., 1974). Recently, Ricou et al. (1974) presented a new hypothesis, suggesting that the ophiolites are derived from the central Tethys and thrusted across the "Taurus calcaire" which is interpreted as an extension of the Arabic platform (Ricou et al., 1975). According to this hypothesis all the ophiolites of Turkey originated in one single oceanic basin. This interesting hypothesis, however, does not encompass all the problem areas and at present we believe the alternative hypothesis of two Mesozoic Basins in the eastern Mediterranean area is more likely (Baroz et al., 1976; Biju-Duval et al., this volume). The ophiolites of central Anatolia then would correspond to the central Tethyan Ocean, whereas the ophiolites of the Cyprus Arc would be relics of an oceanic eastern Mediterranean.

Offshore, both east and northwest of Cyprus, strong magnetic anomalies do not correspond to volcanic structures; they prove the presence of magnetic bodies (pillow lavas - ophiolites) and the continuity of the Cretaceous nappes along the Cyprus Arc below the Antalya and North Levantine basins. Toward the northwest, in Turkey, the Antalya nappes with their Mesozoic ophiolites and sediments were also tectonized at the end of the Cretaceous and then again during the Cenozoic.

Cyprus Arc Front: The front of the Cyprus Arc runs from Lattakia (Syria, Levantine coast) through southern Cyprus and the Florence Rise to the south of the Anaximander Mountains.

On the Levantine coast, the Upper Cretaceous allochthonous series has been affected by young reverse faults, involving the late Miocene evaporite deposits of Lattakia. The offshore prolongation is marked by bathymetric highs and by an elevation of the acoustic basement with seismic evidence of local reverse faults. This frontal part of the Cyprus Arc corresponds more or less to a seismic zone which allowed McKenzie (1972) to define the southern limit of the Turkish plate.

South of the Cyprus Arc, the nature of the crust is not well defined, and the thickness of sediments is very great (Lort, 1974). In the Levantine Basin the crust may be continental or intermediate, below the Herodotus Abyssal Plain, it may be transitional to oceanic.

The Florence Rise thus proves to be a feature of great interest because of (1) the youth of its tectonics resulted in a thin cover of an otherwise thick PlioceneQuaternary sequence. The thinning of the upper evaporites and the pinch-out of the salt layer along the rise allowed us to drill the pre-evaporitic layers and to study the end of the salinity crisis. (2) The accessibility of deep horizons which could be the tectonized basement of the Neogene Basin (i.e., Upper Cretaceous nappes including ophiolites, mélanges, and allochthonous Mesozoic series). If such a basement had been reached, this could have thrown light on the very important problem of the hypothetic Pamphylian Basin (Monod et al., 1974; Ricou et al., 1974).

Unfortunately, only the first objective was achieved; without re-entry the basement could not be reached.

\section{STRATIGRAPHIC FRAMEWORK}

The lithology and the biostratigraphy of the sequences recovered at Sites 375 and 376 have been described in detail in the Site Report 375/376, this volume. The general lithologic succession and a detailed biostratigraphic analysis of the Neogene formations of northern Cyprus, with which Sites 375 and 376 are best compared, have been presented by Baroz and Bizon (1974); excellent sedimentological observations in the Kythrea Group are found in the publications of Weiler $(1964,1965,1969,1970)$. A general stratigraphic correlation between northern Cyprus and Sites 375 and 376 is presented in Table 1; detailed lithological and biostratigraphic correlations in Figure 3.

\section{Quaternary}

On Cyprus, the Quaternary is essentially continental. Beach deposits are restricted to marine terraces near the actual coastlines. From the early Quaternary onwards Cyprus was emergent and subjected to positive epeirogenic movements and the marine terraces indicate different stages of uplift. The Quaternary lithofacies of Cyprus thus are fundamentally different from

TABLE

Stratigraphic Correlation Between the Neogene Sequences of Northern Cyprus and Sites 375-376

\begin{tabular}{|c|c|c|c|c|c|}
\hline & $\operatorname{Leg} 42 \mathrm{~A}$ & \multicolumn{4}{|c|}{ Northern Cyprus (Baroz and Bizon, 1974) } \\
\hline & $\begin{array}{l}\text { Sites } 375 \\
\text { and } 376\end{array}$ & \multicolumn{2}{|r|}{ Pentadaktylos Range } & \multicolumn{2}{|c|}{ Mesaoria } \\
\hline Quaternary & Unit I & \multicolumn{4}{|c|}{ Continental and sandy beach deposits } \\
\hline Late Pliocene. & Unit II & \multicolumn{4}{|c|}{$\begin{array}{l}\text { Athalassa Formation } \\
\text { Nicosia Formation }\end{array}$} \\
\hline Early Pliocene & Units III-IV & \multicolumn{4}{|c|}{ Myrtou Marls } \\
\hline Messinian & $\begin{array}{l}\text { Unit V } \\
\text { Unit VI }\end{array}$ & \multirow{9}{*}{ 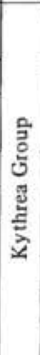 } & Lapatza Formation & \multirow{4}{*}{ 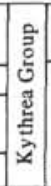 } & Lapatza Formation \\
\hline Tortonian & Unit VII & & Davlos Sandst. & & \multirow[t]{2}{*}{ Mia Milea Formation } \\
\hline Serravallian & $\begin{array}{l}\text { Unit VIII } \\
\text { Unit IX }\end{array}$ & & Trapeza Marls & & \\
\hline Langhian & Unit $\mathrm{X}$ & & Panagra Marls & & Panagra Marls \\
\hline Burdigalian & Unit XI & & Flamoudi Sandstones & \multirow{5}{*}{\multicolumn{2}{|c|}{ Lefkara Chalks }} \\
\hline Aquitanian & & & & & \\
\hline \multirow{3}{*}{ Oligocene } & & & Klepini Siltstones & & \\
\hline & & & Bellapais Formation & & \\
\hline & & & Kythrea Conglomerate & & \\
\hline
\end{tabular}




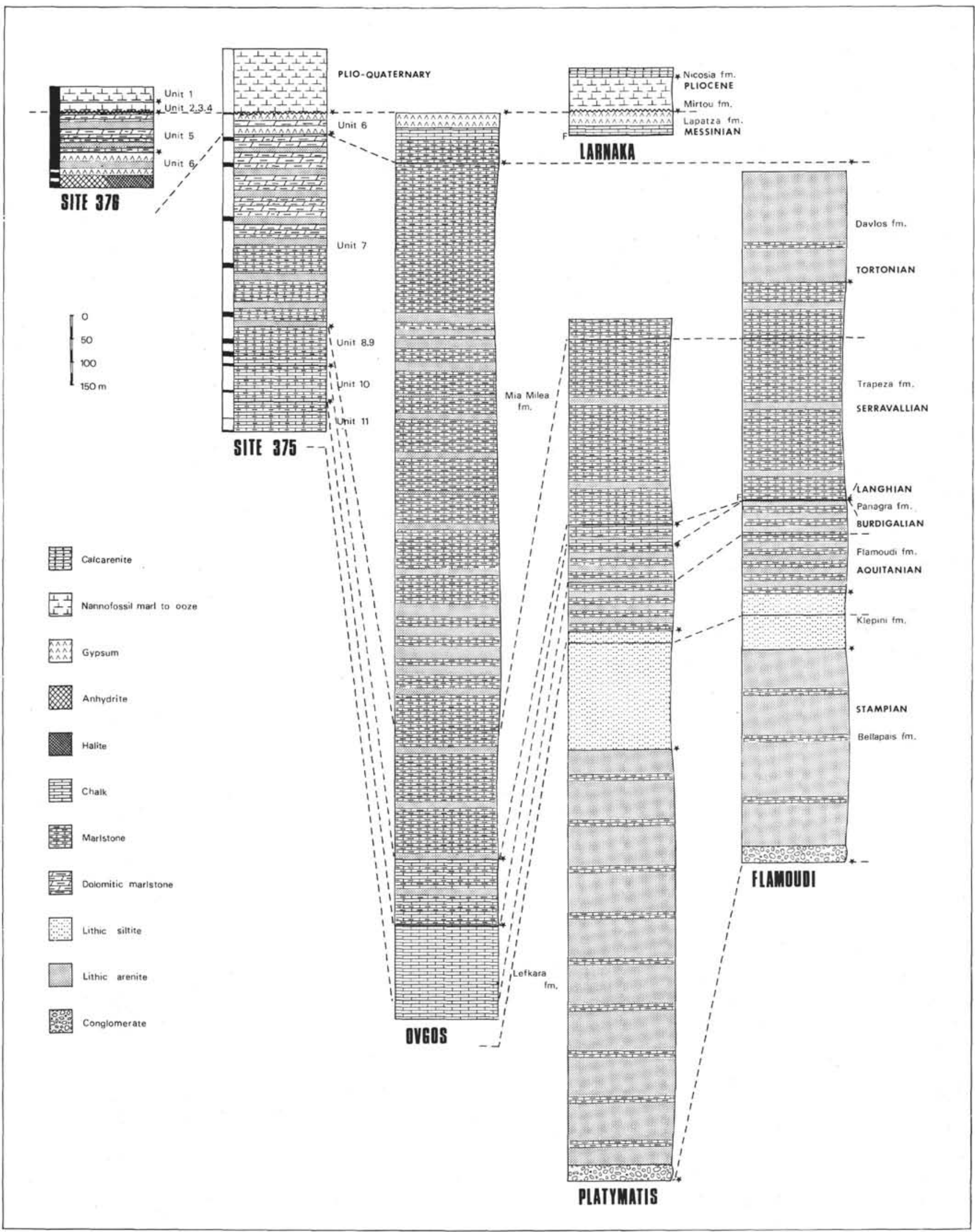

Figure 3. Stratigraphic correlation between Neogene sequences of Northern Cyprus and Sites 375 and 376. Formation thicknesses at Site 375 corrected according to recommendation in Site 375/376 Report, this volume. 
the pelagic and hemipelagic deposits at Site 376 and no comparison can be made.

\section{Pliocene}

The Pliocene crops out widely along the southern border of the Pentadaktylos Range and around the Troodos massif. In northern Cyprus the upper part of the Pliocene ( $G$. crassaformis and $G$. puncticulata zones) are represented by the Athalassa Formation (above) and the Nicosia Formation (below). Both formations are rare in planktonic foraminifera and are of shallow-water origin. Their facies,-calcarenites, bioclastic limestones and marls in the Nicosia Fm, sandy marls, breccias and conglomerates in the Athalassa Fm.-cannot be compared with the coeval deposits at Sites 375 and in 376.

The lower part of the Pliocene consists of marls with a rich benthonic and planktonic microfauna (Myrtou Marls). In the Mesaoria, where the formation is thicker than 300 meters, the Myrtou Marls overlie the evaporites of the late Miocene Lapatza Formation with an angular unconformity and a basal conglomerate with gypsum pebbles. Along the Troodos, the Pliocene is locally transgressive directly onto the pillow-lavas of the Troodos (Pissouri Formation). In a general way the Myrtou Marls are comparable with the Pliocene oozes of Unit IV, Site 376. The Myrtou Marls, however, appear to be deposited in shallower and more oxygenated waters (absence of sapropels), whereas Unit IV, Site 376 , appears to be stratigraphically condensed.

\section{Miocene}

Two different depositional areas are recognized in Miocene sediments on Cyprus. To the north and to the south of the late Eocene Pentadaktylos range, the turbiditic and hemipelagic sediments of the Kythrea Group (Oligocene-late Miocene) were deposited. To the south of the Ovgos Fault the Troodos Massif was the site of pelagic sedimentatic $\eta$ (Lefkara and Pakhna formations) which started durin ${ }_{0}$ the Paleocene on the northern flank and during the Maestrichtian along the southern flank of the massif. The onset of the salinity crisis in the late Miocene lead to deposition of evaporites (Lapatza Formation) in the Kythrea Basin and to reefoidal limestones, evaporites, and unconformities along the margins of the Troodos.

The Miocene sediments recovered at Sites 375 and 376 are comparable with those of the Kythrea Group. Detailed comparisons of lithologic and biostratigraphic characteristics are presented below.

\section{Oligocene}

Oligocene sediments were not reached at Sites 375 and 376. In the Kythrea Basin the Oligocene is represented by the Klepini Siltstones (above), and the Bellapais Formation (below). The Klepini Siltstones consist of an alternation of fine distal turbidites and hemipelagic to pelagic marls and limestones rich in planktonic foraminifera. The Bellapais Formation in turn is made up by a cyclic alternation of graded lithic arenites, siltites, and marlstones. At the base of the Kythrea Group a formation of pebbly mudstones (Kythrea Conglomerate) occurs which unconformably overlies the late Eocene ancestral Pentadaktylos Range.

\section{LITHOLOGY}

In this section we describe the lithological analogies between the Miocene sequence at Sites 375-376 and the Kythrea Group of northern Cyprus. We restrict ourselves to the formations encountered during Leg $42 \mathrm{~A}$ on the Florence Rise; for a detailed lithological description of the Kythrea Group the reader is referred to Baroz (1977) and the earlier work of Weiler (1965).

\section{Lapatza Formation and Units V and VI, Sites 375 and 376}

On Cyprus, the Lapatza Formation consists in its lower part of marls, chalks, and sediments rich in organic matter; it is late Miocene (Messinian) in age and contains in its upper part the Mediterranean Evaporites which also constitute Unit VI at Sites 375 and 376. In outcrop the evaporites are essentially gypsum, however, from the center of the Mesaoria Basin about 300 meters of rock salt are reported from boreholes (Gass, 1960). Along the margins of the Mesaoria the evaporites are overlain with an unconformity by pelagic marls of the early Pliocene (Myrtou Marls).

Site 376 has been drilled on the margin of the Antalya Basin where the thick layer of rock salt present pinches out towards the Florence Rise. Here only the uppermost part of the Mediterranean Evaporite, consisting of alternating anhydrite and rock salt overlain by about 50 meters of gypsum, has been drilled. The evaporites are overlain in turn by 92 meters of variegated to drab and greenish gray, partly dolomitic marlstones with interbedded graded sandstones and siltstones (Unit V, for a detailed description see Chapter 6). The absence of burrowing invertebrates and the restricted character of the in site fauna suggests unfavorable environmental conditions. These marlstones and turbidites were probably deposited in relatively shallow water with reduced salinity. Deposits corresponding to Unit $\mathrm{V}$ are not known from Cyprus.

At Site 375 which is situated near the top of the Florence Rise nearly 50 meters of gypsum was drilled. The lower contact of the evaporites was not recovered and we do not know if the absence of early Messinian pelagic sediments is primary or due to spot coring and poor recovery. The presence of highly altered carbonates near the base of the evaporites (Calcare di base) together with the structurally elevated position of the site suggests the first interpretation, according to one of us (D.B.).

\section{Evaporites}

On northern Cyprus the evaporites of the Lapatza Formation generally occur as chaotic masses of gyp- 
sum tectonically fragmented and separated from their stratigraphic substratum. Different types of gypsum were noted:

1) Impure gypsum. This variety occurs as dmbedded, white, fine-grained gypsum with a chalky appearance and thin yellowish marl interbeds. In thin section, mainly gypsum and some minor amounts of anhydrite $(20 \%)$ are present. The crystal boundaries are not very distinct and the crystals appear as unoriented, finely interlocking grains. Micrite is finely dispersed in the sulfates and no chicken-wire structure was seen in this rock. Coccoliths are rare in the micrite and planktonic foraminifera are absent, but large diatoms, partly replaced by gypsum, are common. Clay minerals comprise montmorillonite $(70 \%-80 \%)$, attapulgite (20\%), illite and kaolinite (each 5\%), and traces of chlorite.

2) Laminated gypsum. Laminated gypsum occurs as beds, 2 to $20 \mathrm{~cm}$ thick, of finely $(1-3 \mathrm{~mm}$ ) laminated gypsum separated sometimes by minute marly to chalky interbeds. Sometimes the laminations are deformed by penecontemporaneous slumping. The laminae are composed alternatively of microcrystalline gypsum with or without larger acicular crystals of anhydrite. These anhydrite crystals are randomly oriented giving to the laminae a typical meshwork structure under crossed nicols.

3) Saccharoidal gypsum. Saccharoidal gypsum is the most common type of gypsum in Cyprus, occurring in large masses intercalated with the other types of gypsum. It is medium to coarsely grained and brown, grayish to greenish or white.

4) Selenitic gypsum. Selenitic gypsum is closely associated with the saccharoidal type and occurs as accumulations of elongated crystals or as clusters which appear to have grown in situ. Swallow-tail twins are very common.

The sedimentary petrology and the structures of the Mediterranean Evaporite are described in detail by Garrison et al. (this volume). At Site 375 only gypsum overlying a few fragments of brecciated and dolomitized limestone were found and the following types of gypsum are recognized: Selenitic gypsum occurs as large crystals, oriented vertically or at high angles to bedding. It apparently grew subaqueously, sometimes displacing green sandy marly sediment; or as piles of randomly oriented, elongated or broken, irregularly shaped crystals, which are interpreted as reworked layers. Reworked gypsum also occurs in clastic layers of poorly sorted, angular sand- to gravel-size particles in a fine-grained micritic matrix. Finely laminated, normally graded gray gypsum layers are also interpreted as having been redeposited. A different type of laminated gypsum (Balatino) consists of couplets composed of relatively coarse-grained gypsum crystals which appear to have grown upward from the sea floor, overlain by fine-grained laminae of oriented, elongated gypsum flakes characteristic of precipitation at the air-water interface. In general the sequence appears to be characterized by in situ growth of gypsum crystals and current-redeposition of detrital gypsum and other components.

At Site 376 recovery in the evaporites was poor and consist of drilling fragments whose stratigraphic context is commonly uncertain. There is a general evolution from saline deposits (anhydrite and halite, Unit VIb) through in situ growth of gypsum in relatively shallow water (Unit VIa) to deeper-water deposition of turbiditic and fine-grained sediment (Unit V). In the upper part of Unit VIa (Cores 16-8), mainly detrital gypsum is present. Gypsarenites contain monocrystalline gypsum clasts and selenite fragments, an admixture of reworked planktonic and benthonic foraminifera and detrital material including serpentine minerals, pyroxene, basaltic rock fragments, and a small amount of quartz. Gypsrudites are predominantly composed of selenite fragments. Beside the clastic gypsum, laminated gypsum as at Site 375 , alabastrine gypsum, and selenitic gypsum which has grown displacively in the green marly sediment, are present.

The lower part of Unit VIa contains a smaller admixture of terrigenous material. It consists of generally well-sorted gypssiltites to fine gypsarenites, which in part are finely laminated; some dark wavy laminae may be stromatolitic.

Unit VIb consists of banded halite and banded and nodular anhydrite which shows typical chicken-wire structure and enterolithic folding. The anhydrite is interpreted as of sebkha-type origin and accordingly the halite as deposited in shallow water.

\section{Pre-evaporitic Sediments of the Lapatza-Formation}

At Site 375, no sediments corresponding to the preevaporitic Messinian sediments of Cyprus were found. On Cyprus, the evaporites are underlain by a sequence of fine-grained marly and chalky sediments which gradually pass downward into the Trapeza Marls and the Mia Milea Formation.

The pre-evaporitic sediments of the Lapatza Formation comprise different lithological types which gradationally and by alternation pass from ochre to orange marls at the base through white marls with a rich planktonic microfauna into white coccolith chalks and dark red or black sapropelic coccolith chalks. The generally fine-grained sediments consist of various mixtures of biogenic carbonate, coccoliths, planktonic foraminifera, and clay minerals. As in the main part of the Kythrea Group, montmorillonite is the dominating clay mineral ( $50-90 \%$ of the clay minerals) with some attapulgite $(10-20 \%)$, illite $(10-20 \%)$, and minor amounts of kaolinite (traces to 15\%) and chlorite (traces). Additionally cineritic quartz, biotite (partly altered to chlorite), and fragments of volcanic glass are present, terrigenous detrital material is rare to absent. Gypsum and anhydrite occur as diagenetic minerals.

A particular facies is represented by the sapropelic coccolith chalks. These occur as thin intercalations between the white marls or more frequently at the top of the sequence. They are finely laminated with alternations of dark, organic matter-rich and gray, cocco- 
lith-rich layers. The dark red varieties of this facies contain a reworked fauna of Tortonian foraminifera; in the blackish facies a well-preserved Messinian fauna has been found, and at places fish (Siphonostroma albyi) remains have been found in this facies (Moore, 1960). Compared with the underlying Tortonian deposits, the pre-evaporitic Messinian sediments show a marked decrease in terrigenous materials. At the time of deposition of these sediments episodic stagnation of the bottom waters may have heralded the beginning of the salinity crisis of the Mediterranean.

\section{Mia Milea Formation and Unit VII, Site 375}

The Mia Milea Formation is regionally the most widely distributed lithologic unit in northern Cyprus and most of the lithologic descriptions of the Kythrea Flysch refer to it. It corresponds to lithosome " $b$ " of Weiler (1969, 1970). Baroz and Bizon (1974) estimated the thickness of the unit as 1600 meters, Weiler (1969) as 1500 meters pointing out that in the central parts of the basin (central Mesaoria) thicknesses might be much higher (up to $3 \mathrm{~km}$ ). At Site 375, Unit VII corresponds to the Mia Milea Formation; it is between 389 and 446 meters thick. At this site, the unit is essentially Tortonian in age, in northern Cyprus where more proximal deposits are present, the facies starts lower in the Serravallian.

The Mia Milea Formation and Unit VII show a distinctly cyclic development which is also described by Weiler $(1965,1969,1970)$ and in the Sites 375/376 report, this volume. The cycles typically have a sharp lower boundary and start with coarse to fine terrigenous arenite and siltite; this grades through fine siltstone into homogeneous and structureless marlstone which is burrowed only at the top and which is overlain by somewhat lighter colored marlstone with sparse burrowing. The thickness of individual cycles varies between $10 \mathrm{~cm}$ and more than 1 meter at Site 375. In Cyprus thicker cycles appear to be more common. The cycles may be incomplete and comprise only the graded and laminated to homogeneous interval and burrowed marlstones, respectively. The graded and laminated sand- and siltstones are interpreted as turbiditic deposits $\left(T_{a}-T_{d}\right.$ of Bouma, 1962). The homogeneous non-burrowed layers, into which the sandstones and siltstones grade, obviously represent the finest fractions transported by the turbidity currents ( $\mathrm{T}_{\mathrm{e}}$ of Bouma, 1962; Weiler, 1969, 1970). If they occur independently from graded sands and silts, they are very distal turbidite deposits (for other examples see Bernoulli, 1971, Hesse, 1975). The burrowed marlstones, finally, are the "normal" hemipelagic deposits. The turbiditic sandstones and siltstones usually have very sharp lower boundaries which obviously are erosional surfaces above the underlying marlstone. At Site 375 these surfaces could only be observed in profile, but from the Mia Milea Formation a wealth of flysch-type bottom marks including flute casts, tool marks, and load casts has been illustrated (Weiler, 1965). The paleocurrents measured were predominantly from east to west parallel to the axis of the basin. Lower surfaces show also casts of organic traces (e.g., Palaeodictyon). Internal structures comprise graded bedding and parallel lamination; small-scale ripple and convolute laminations are frequent in the Mia Milea Formation, but were only rarely seen in the Site 375 sediments.

Compositionally the arenites and siltites are lithic sandstones or "graywackes" containing lithic fragments of altered mafic volcanics, serpentinites, metamorphics, detrital carbonate, quartz, feldspars (mainly plagioclase), volcanic glass and heavy minerals (amphibole, biotite, epidote etc.) (Figure 4). In the Mia Milea Formation part of the lithoclasts are derived from older formations now cropping out in the Pentadaktylos Range, these comprise Triassic or Jurassic radiolarites, Triassic dolomites, Jurassic crystalline limestones, and fine-grained pelagic limestones, cherts and skeletal calcarenites from the Upper Cretaceousmiddle Eocene Lapithos Group. Additionally, there are fragments of displaced shallow-water organisms such
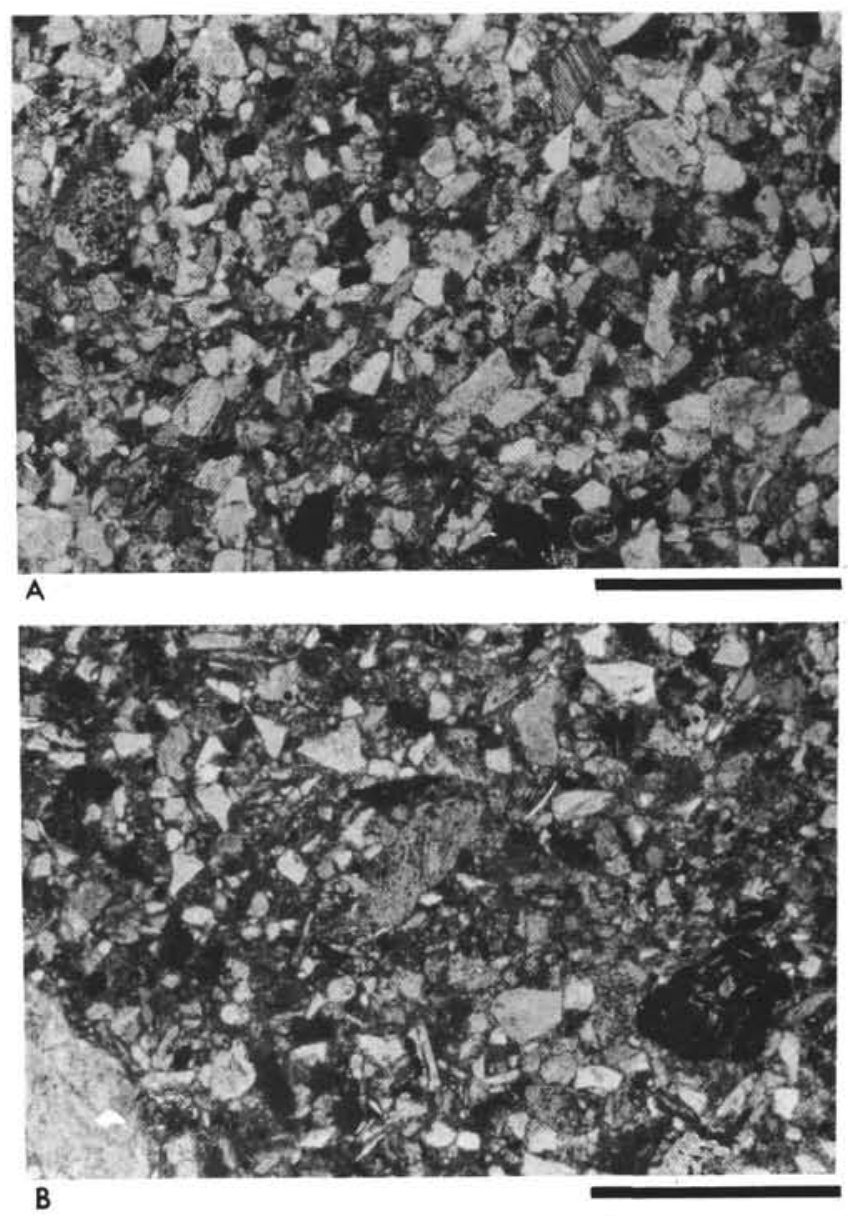

Figure 4. Lithic arenites ("graywacke") containing lithic fragments of altered volcanic, carbonate and metamorphic rocks and quartz, feldspar, heavy minerals (mainly amphibole), and rare mica in a ferroan carbonate matrix. (A) Ech. 2, Mia Milea Formation, Tortonian. Sampled on the road between Nicosia and Kerinia. (B) Unit VII, Site 375, Tortonian, Sample 375-6-1, 5-9 cm. Thinsections, scale bars: $1 \mathrm{~mm}$. 
as red algae, bryozoa, larger benthonic foraminifera, and frequent reworked planktonic foraminifera of Late Cretaceous to Eocene age. The clay minerals are essentially the same as in the associated marlstones with somewhat greater amounts of illite and kaolinite $(0-10 \%)$.

The turbiditic marlstones contain mainly finegrained carbonate (coccoliths and detrital) and clay minerals with minor amounts of detrital minerals. At Site 375 dolomite is particularly common in the upper part of the unit; as shown by X-ray diffraction analysis (Müller, this volume), both detrital (stoichiometric) and neomorphic (calcian) dolomites occur. From the Kythrea Group Weiler (1970) has reported chlorite and illite as the dominant clay minerals with only minor amounts of montmorillonite. Our analysis (see also Mélières et al., this volume) did not confirm his findings; they indicate smectites as the dominant clay minerals with associated chlorite, attapulgite, mixedlayered clay minerals (10-14) and only very small amounts to traces of illite and kaolinite.

The hemipelagic, sparsely burrowed marlstones are different from the turbiditic ones by their generally lighter color, which is medium bluish gray to greenish and olive-gray at Site 375 and yellowish white in outcrop. Their composition is essentially the same as that of the turbiditic marlstones with somewhat higher carbonate contents (Figure 5[B]). The contact with the underlying turbiditic marlstones is typically modified by burrowing, generally Chondrites-type burrows, in which lighter sediments have been piped down into the darker sediments (see also Sites 375, 376 reports, this volume, Fig. 12 and Weiler, 1965, 1969). Burrows in the hemipelagic marlstones are of Chondrites-type with minor occurrences of Planolites and occasional Zoophy$\cos$.

In addition to the terrigenous turbidites, skeletal calcarenites occur, which are exclusively composed of plaktonic foraminifera (Figure 5[A]). They occur as thin graded beds (up to $10 \mathrm{~cm}$ thick on Cyprus) and fine laminae with size-sorted small foraminifera (Site 375).

Layers high in organic matter (sapropels) occur both on Cyprus and at Site 375. They are distinguished from the dominant nannofossil marlstones by a higher organic content and by a typical flaser-structure. The occurrence of graded bedding and lamination, however, indicates that some of the sapropels are redeposited.

Unit VII and Mia Milea Formation were laid down in a subsiding basin which was semireducing and episodically even stagnant as shown by the abundance of organic matter (sapropels) and pyrite, sparse burrowing, and poor benthonic assemblages. Deposition of hemipelagic marls was episodically interrupted by the deposition of turbiditic sandstones and siltstones. The sedimentary material of these turbidites is clearly derived from the east. This is shown by decreasing grain size and bed thicknesses towards the west, an increase in distal deposits in the same direction and the east-west orientation of linear bottom marks (Weiler,
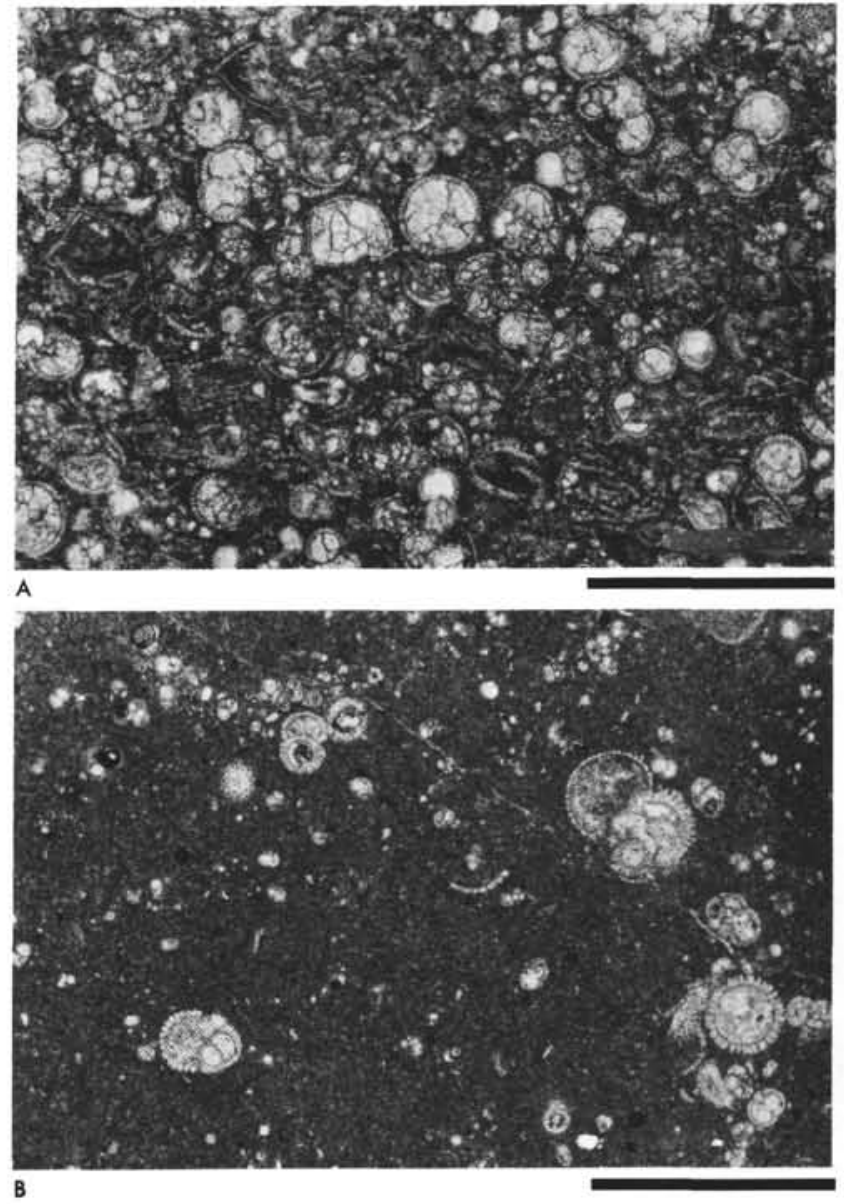

Figure 5. Typical microfacies of pelagic and hemipelagic sediment in Mia Milea Formation and Unit VII, Site 375. (A) Marly foraminiferal packstone with closely packed, partly crushed planktonic foraminifera in a fine marly matrix. Mia Milea Formation, Tortonian, Ech. 193. Sampled on the road between Mia Milea and Koutsovendis. (B) Marly foraminiferal wackestone with planktonic foraminifera set in a matrix of nannofossil marl. Site 375, Unit VII, Tortonian, Sample 375-5-6, 85-86 cm. Thin-sections, scale bars: $1 \mathrm{~mm}$.

1964, 1965). According to Weiler (1970), the clastic material comes from extensive deltas of the ancestral Ceyhan and Seyhan rivers which drained large areas of the Tauride and Misis mountains during the Miocene. In view of its limited areal extent the ancestral Pentadaktylos Range did not contribute significantly to the large volume of detrital material in the Kythrea Flysch. In particular, the limited occurrences of mafic volcanic (Cretaceous to Paleogene) rocks could not supply the large amounts of volcanic detritus present in the Kythrea Flysch, which evidently is derived from extensive ophiolitic terrances. No sediment was furnished by the Troodos Massif of southern Cyprus, which at this time was the site of pelagic sedimentation.

Weiler (1965) estimated the depth of the late Miocene Kythrea Basin as in the order of 500 to 1000 meters. The generally poor benthonic assemblages, which at least in part are displaced downslope, indicate 
at least a low epibathyal environment (Site 375/376 Report, this volume). The trace fossil assemblage, Chondrites with minor occurrences of Planolites and Zoophycos, is that usually found in fine-grained sediments of relatively deep and quiet waters (Ekdale, this volume).

\section{Davlos Sandstones}

The Davlos Sandstones are restricted to the eastern part of northern Cyprus, to the north and the south of the Pentadaktylos Range. They consist of a 250-meter thick cyclic sequence of coarse lithic sandstones, siltstones, and marlstones which laterally grade into the Trapeza Marls toward the west.

The davlos Sandstones are of the same age (upper Tortonian) as the upper part of the Mia Milea Formation of the Mesaoria and of Unit VII, Site 375 and are interpreted as a more proximal facies deposited in the same basin. In fact, the cyclic development of the Davlos Sandstones is very similar to that of the Mia Milea Formation and the petrographic composition of the clastic material is the same.

The sedimentary cycles consist of brownish to greenish gray, coarse lithic sandstone, sometimes with granules along their base, which grade through sandstone and siltstone into greenish yellow to light brown structureless marlstone. Often the cycles are truncated at their tops and yellowish white, burrowed marlstones of hemipelagic origin are only occasionally present: the lower surfaces of the lithic sandstones are clearly erosional and the sandstones frequently contain marlstone pebbles, sometimes of an older age.

The lithic arenites contain fragments of mafic volcanic rocks, serpentinites, and/or of sedimentary rocks, mainly carbonates, and rare metamorphics (Figure 6). The sedimentary fragments comprise the same types

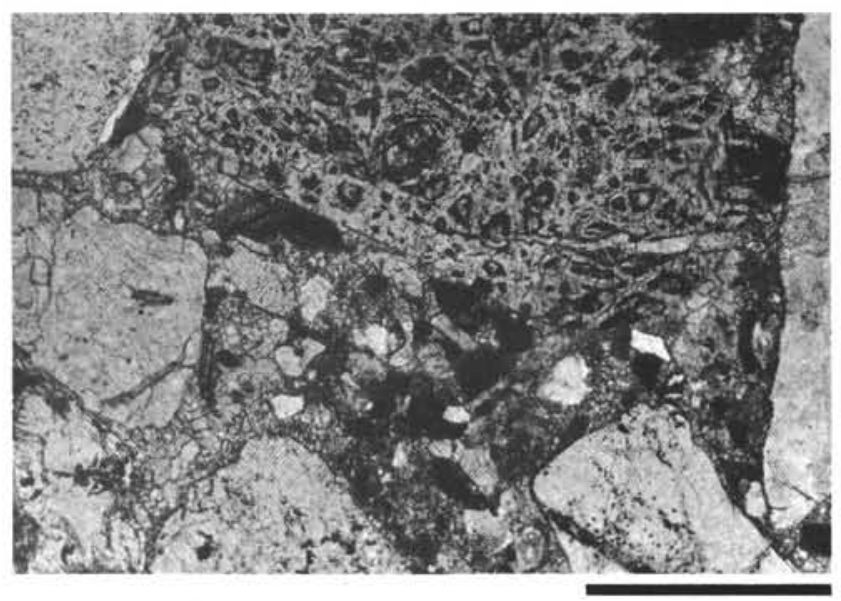

Figure 6. Davlos Sandstone. Lithic microbreccia composed of fragments of serpentinite, altered mafic volcanic rocks, radiolarite, radiolarian-rich and other pelagic limestones, oolitic limestone, crystalline carbonate rocks, etc.; all cemented by calcite. Ech. 209, St. 319, sampled on the road between Davlos and Komi Kebir. Thin-section, scale bar: $1 \mathrm{~mm}$. already mentioned from the Mia Milea Formation and also the detrital and clay mineral association is essentially the same.

There are white to light yellow, bedded cineritic tuffs intercalated with the marls of hemipelagic origin. The tuffs are composed of fine rhyolitic fragments, acidic devitrified volcanic glass, quartz, muscovite, biotite, augite, alkali feldspars, and some plagioclase and green amphibole with an admixture of globigerinids and other calcitic remains in the finer grain sizes. Other types present a hyaloclastic texture with welded glass fragments.

Cineritic tuffs have also been described by Weiler (1965) from the Kythrea Flysch in general, but at Site 375 , only traces of volcanic glass were found.

\section{Trapeza Marls, Units VIII and IX, Site 375}

In northern Cyprus the Mia Milea Formation passes laterally into the Trapeza Marls, dark marls with some lithic arenites and siltstones of Serravallian to Tortonian age. (Table 1). At Site 375, the Serravallian is represented by variegated and dark colored mudstones, marlstones, and marly limestones which comprise Units VIII and IX. The thickness of the Trapeza Marls has been estimated as 500 meters by Baroz and Bizon (1974); at Site 375, Units VIII and IX are approximately 75 meters thick.

The Trapeza Marls and Units VIII and IX, Site 375, also show a typically cyclic development of $\mathrm{cm}$ - to $\mathrm{dm}$ alternations of dark siltstones to marlstones and light colored foram-nanno marlstones to limestones. In the Trapeza Marls the cycles may start with a sharp lower contact above which 10 to $20 \mathrm{~cm}$ of fine light colored lithic arenite grade into siltstone and into bluish gray to dark gray homogeneous marlstones. Intercalated within the dark marlstones, thin beds $(1-2 \mathrm{~cm})$ of yellowish white marlstones occur which are distinguished from the darker lithologies by their higher carbonate content and the presence of planktonic foraminifera. At Site 375 , graded laminae of terrigenous and bioclastic fine sand or silt occur only rarely at the base of the cycles (Figure 8), (Site 375/376 Report, this volume, fig. 13). Generally the cycles start with dark structureless mudstone and marlstone with a sharp lower boundary. They gradually pass upward into the more calcareous and foraminifera-rich, light colored marlstone to limestones (Figure 9). Typically the top of the mudstone layers are intensely burrowed from above, with burrows filled by light colored foraminifera-rich sediment. Examples of this are shown in Figure 7 and have also been illustrated by Weiller (1969, fig. 4). Burrows are of the Chondrites, Planolites, and Zoophycos type. Different types of Zoophycos are the predominant type of burrow in Unit IX at Site 375 (Site 375, 376 Report, this volume, fig. 13).

The fine arenites of the Trapeza Marls contain mainly calcitic fragments and only up to $20 \%$ of volcanic detritus including volcanic glass, biotite and cineritic quartz. The homogeneous marlstone and mudstones generally are composed of micritic carbonate (mainly nannofossils), various amounts of clay miner- 


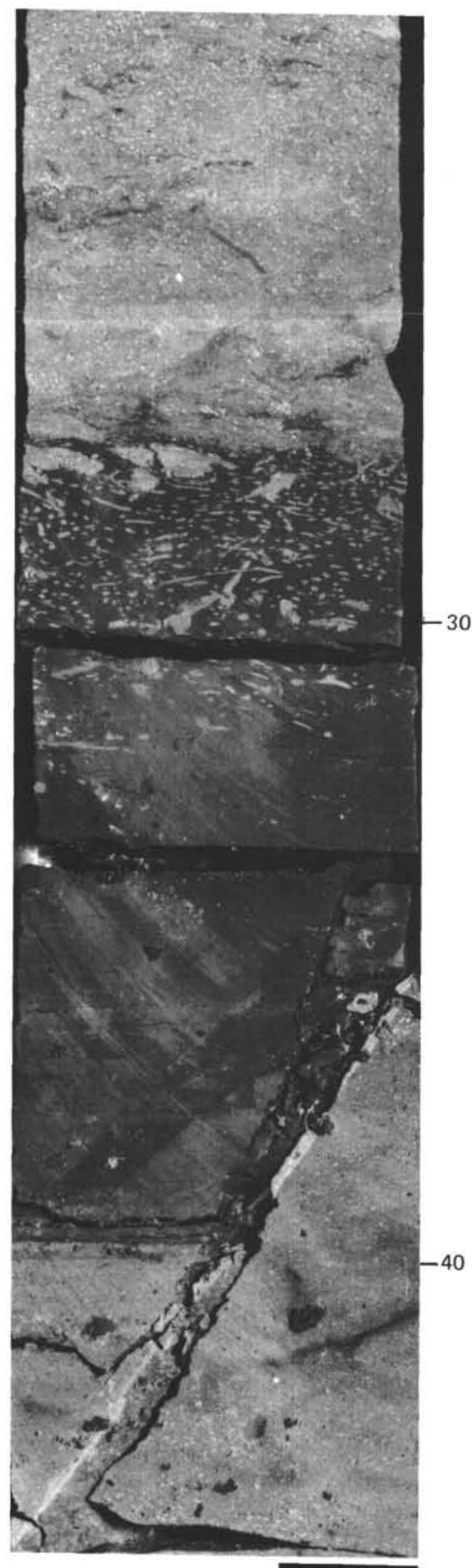

Figure 7. Characteristic cycle in Unit IX, Site 375. Faintly laminated dark gray marlstone with sharp lower boundary, overlain by light gray, foraminifera rich more calcareous marlstone. The uppermost part of the dark marlstone is bur- rowed (Chondrites) with light sediment piped down from the light calcareous marlstone above. The dark marlstone is interpreted as a (distal) turbiditic mudstone, the more calcareous lithology as a more slowly deposited hemipelagic sediment (cf. also Weiler, 1969, fig. 4). Unit IX, Serravallian. Sample 9-1, 21$40 \mathrm{~cm}$, scale bar: $2 \mathrm{~cm}$.

als and only small amounts of detrital fragments. As in the other formations of the Kythrea Group, smectites are the dominant clay minerals with associated attapulgite, some chlorite, illite, and kaolinite. Some of the homogeneous marlstone is rich in organic matter (sapropels).

The dark homogeneous mudstones and marlstones in Units VIII and IX are interpreted as distal turbidites. This interpretation is supported by the graded and convolute sandstones and siltstones associated with the marlstones in the Trapeza Marls. The light colored foraminifera-rich sediments could represent slower pelagic to hemipelagic deposition in a basin whose bottom waters were slightly oxidized at times and reducing at others, as shown by the occasionally occurring sapropelic layers. The gradual passage from more proximal turbidite facies in Cyprus to very distal ones at Site 375 is in line with the general east-west paleocurrent directions in the Kythrea Group.

\section{Panagra Marls, Unit X, Site 375}

This unit of Langhian age is a good lithologic marker within the Kythrea Group of northern Cyprus (Moore, 1960). Weiler $(1965,1969)$ has included it into the Ovgos Formation and interpreted it as a marginal facies restricted to the southern border of the

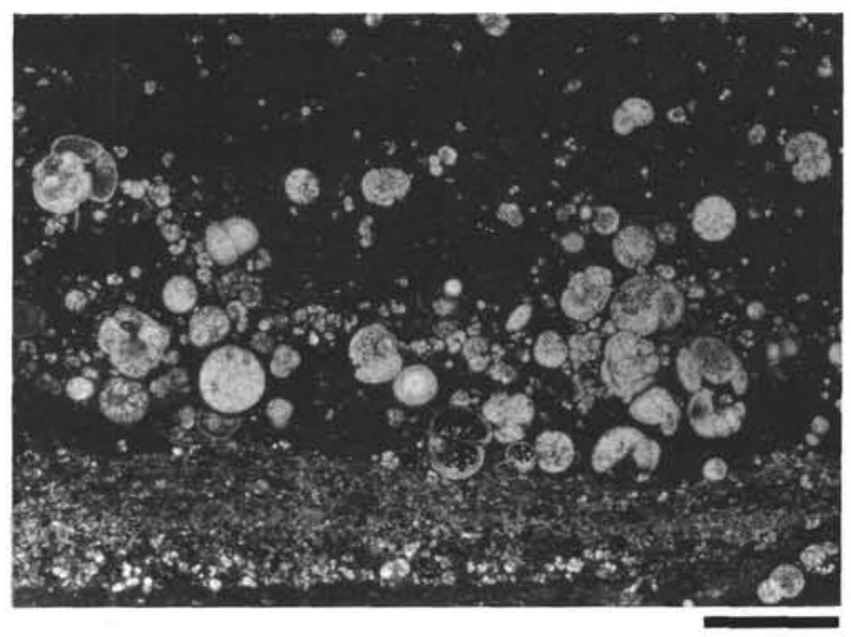

Figure 8. Typical microfacies of Unit IX, Site 375. Marly wackestone with planktonic foraminifera and with laminae of size-sorted small foraminifera and skeletal debris, the foram tests are partly filled by pyrite. Site 375, Unit IX, Serravallian. Sample 375-9-5, 17-23 cm. Scale bar: $1 \mathrm{~mm}$. 

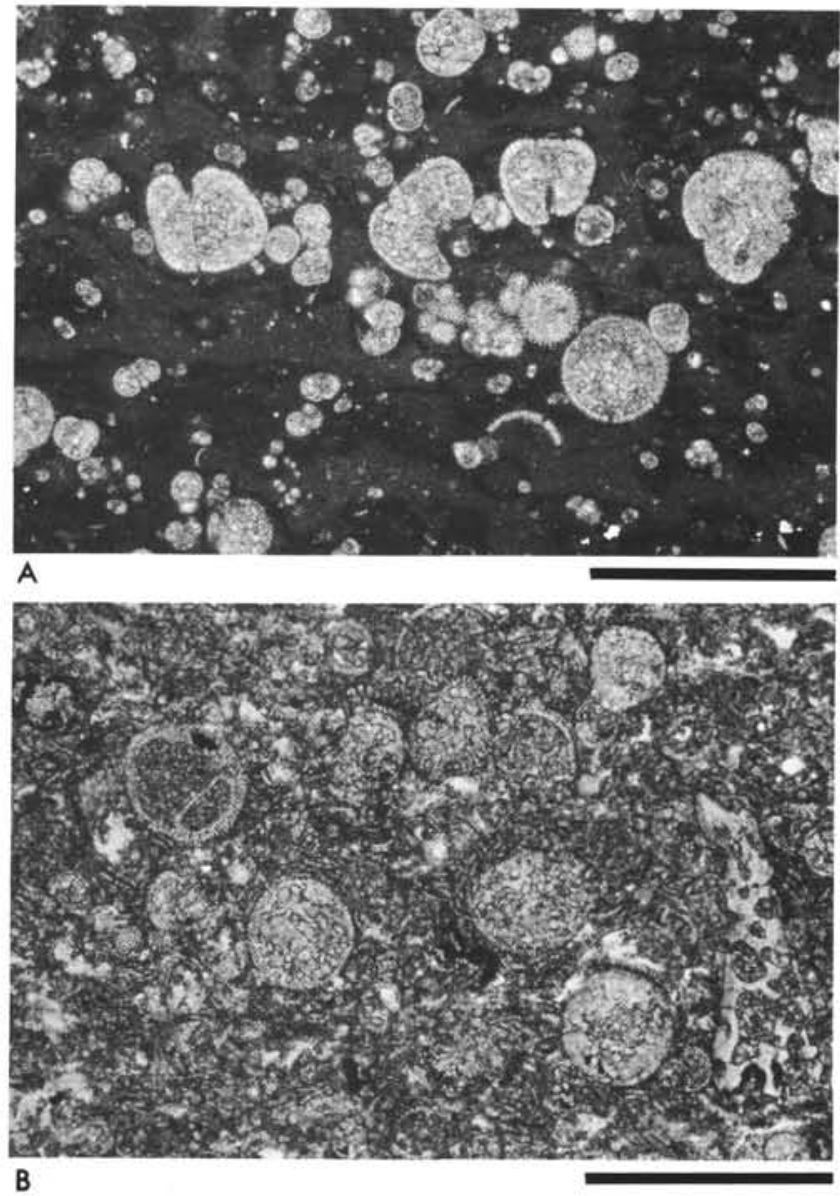

Figure 9. Typical microfacies of Trapeza Marls and of Unit IX, Site 375. (A) Marly wackestone with planktonic foraminifera, filled by ferroan calcite cement. Site 375, Unit IX, Serravallian, Sample 375-9-1, $25 \mathrm{~cm}$. (B) Foraminiferal lime packstone with many crushed foraminiferal tests. Trapeza Marls, Serravallian, B 335. Sampled near Eptakomi, in Yiotis forest. Thin-sections, scale bars: $1 \mathrm{~mm}$.

Kythrea Basin, but Baroz and Bizon (1974) showed that it also underlies most of the Mia Milea Formation in the central parts of the Mesaoria Basin. It also occurs north of the Pentadaktylos Range. Its facies is very constant from northern Cyprus to Site 375 where it constitutes Unit X. The Panagra Marls are distinguished from the other members of the Kythrea Formation by their high carbonate content, the abundance of large planktonic foraminifera and the brick red to brownish red color. For these reasons and for general similarity of facies with the Ammonitico Rosso of the Tethyan Jurassic, Unit $\mathrm{X}$ was informally called the "Orbulinico rosso" aboard the ship.

Different kinds of cycles occur in this unit. At Site 375 cycles similar to the ones described from the Trapeza Marls and Units VIII and IX occur. They consist of greenish gray to grayish blue-green marlstone with sharp lower boundaries grading into reddish brown marlstone with foraminifera-rich and foraminifera-poor layers and with sparse Chondrites and Zoophycos type burrows.
Again the lower part of the cycles are interpreted as distal turbidites composed of redeposited fine terrigenous and hemipelagic material. These turbidites may correlate with the more proximal turbiditic sandstones found in the Panagra Marls of Cyprus. These are light gray or dark red lithic arenites in beds of 10 to $20 \mathrm{~cm}$, which show sharp lower boundaries, graded bedding and parallel and convolute laminae. The lithic arenites contain fragments of mafic volcanics and serpentinite, volcanic glass, quartz (in part of cineritic origin), feldspar, biotite, muscovite, chlorite, pyroxene, amphibole, etc. in an argillaceous to micritic matrix. The lithic fragments of sedimentary rocks comprise crystalline limestones, cherts, micritic limestones, and quartzites, and a small admixture of micritic intraclasts, glauconite, and planktonic and benthonic foraminifera.

Beside these distal terrigenous turbidites, light gray to bluish white, hard, cemented limestones occur in the Panagra Marls and at Site 375 . Typically they have sharp lower boundaries; some are distinctly graded and have parallel, small-scale current and convolute laminations (Site 375/376 Report, this volume, fig. $14)$. They pass gradually into gray or red marlstones. Others are up to several $\mathrm{cm}$ thick and have sharp lower and upper boundaries and no obvious grading. Both types are exclusively composed of planktonic foraminifera which are tightly cemented by syntaxial and blocky, usually ferroan, calcite cement (Figure 10).

A third type of turbidites is restricted to northern Cyprus and has not been found at Site 375. These occur as 5 to $10 \mathrm{~cm}$-thick beds of red skeletal calcarenites intercalated within the red marls. They contain about equal amounts of terrigenous fragments and of skeletal fragments. The terrigenous fraction is mainly chert, micrite, crystalline limestone with an admixture of rare fragments of mafic volcanics, and quartz and feldspar. The skeletal fragments comprise planktonic foraminifera and up to $50 \%$ of broken and iron-stained remains of benthonic shallow-water organisms such as miliolids, rotalids, crinoids, echinoid spines, and red algae (Lithothamnium); all are set in a sparitic cement (Figure 11).

The red and gray marlstones have a higher carbonate content than those of the overlying and underlying units. They are rich in calcareous nannoplankton and planktonic foraminifera. Calcian dolomite occurs as tiny rhombohedra of apparently diagenetic origin. The clay minerals show a great variability with smectites as dominant clay minerals, associated with illite, mixedlayered minerals, kaolinite, and attapulgite at Site 375; in northern Cyprus illite and attapulgite are the prevalent clay minerals with smaller amounts of smectites and chlorite only.

The sediments of the Panagra Marls are derived from different sources. The terrigenous sandstones and siltstones have an eastern origin as most of the clastic material of the Kythrea Group. In fact, at Site 375 only distal turbiditic mudstones and marlstones are present. The turbidites which are composed entirely of planktonic foraminifera are derived from an area with pure pelagic sedimentation, possibly the Troodos high where pelagic sediments were deposited during the 

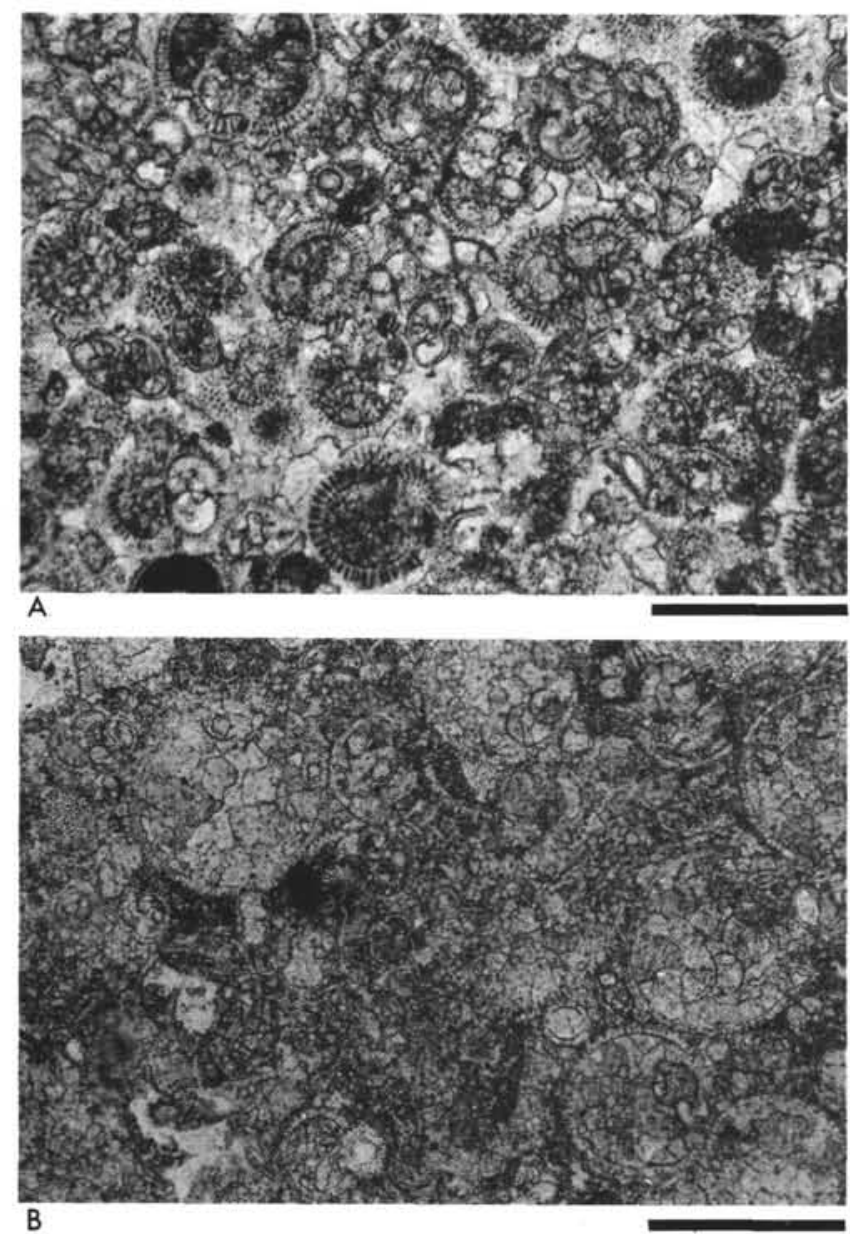

Figure 10. Foraminiferal lime grainstones, composed entirely of planktonic foraminifers and their fragments and cemented by syntaxial and blocky calcite. These rocks are interpreted as pelagic sediments redeposited by turbidity currents ("pelagic" turbidites). Note crushed foraminifera tests in (B). (A) Unit X, Site 375, Langhian, Sample 375-11-1, 125-130 cm. (B) Panagra Marls, Langhian, Sample ML 6117, sampled near Panagra, on the road from Panagra to Mirtou. Thin-sections, scale bar: $0.5 \mathrm{~mm}$.

Langhian. The calcarenites with lithic and shallowwater skeletal fragments must come from still another area; a possible source area could have been in the embryonic Pentadaktylos Range, parts of which may have emerged as a number of islands surrounded by shallow-water areas with reefoidal and open-marine carbonate sedimentation. Such shallow-water facies, however, are not preserved in northern Cyprus, but they crop out widely in southern Turkey where the Langhian is generally transgressive (Bizon et al., 1974).

\section{Flamoudhi Sandstones and Unit XI, Site 375}

Compared with the Langhian to Messinian sequence, the Burdigalian shows a much more pronounced variation of facies. Along the Pentadaktylos Range about 200 meters of bioclastic turbidites and hemipelagic marls are present which laterally pass into more terrigenous turbidites toward the east (Flamoudhi Sandstones). This sequence is of Aquitanian to Burdigalian age. In the Mesaoria Basin (Ovgos Potamos section, Baroz and Bizon, 1974) the lower Miocene consist of some 200 meters of pelagic chalks and interbedded marls (upper Lefkara Formation). At Site 375 recovery in the lower Miocene was extremely poor. It consists of a few fragments of a hard limestone in the core catcher sample of Core 12 and slim core fragments of less than 1 meter of alternating green marl and limestone in Core 13. This facies is interpreted as a distal terrigenous turbidite alternating with hemipelagic marl to limestone (Figure 13), as in Units VIII and IX.

The Flamoudhi Sandstones consist of a cyclic alternation of yellowish lithic and bioclastic sandstones which through siltstones grade into marls. The beds are generally in the order of 10 to $20 \mathrm{~cm}$, but thicker beds (up to $1 \mathrm{~m}$ ) in which complete Bouma cycles are recognized to occur as well. Graded bedding, parallel and convolute lamination, flute and tool marks and trace fossils (Palaeodictyon) are widespread throughout the Flamoudhi Sandstones.

The lithic sandstones contain mainly fragments of carbonate rocks, crystalline limestones and dolomites, oolites, micrites, and chert. Other components are mafic volcanic rocks, volcanic glass, quartz, plagioclase, mica, chlorite and pyroxene, rare intraclasts, and globigerinids. All the components are closely packed with microstylolithic contacts. In places the base of the lithic sandstones is made of coarser bioclastic material.

Bioclastic fragments, together with intraclasts, are also the main components of graded calcarenites.

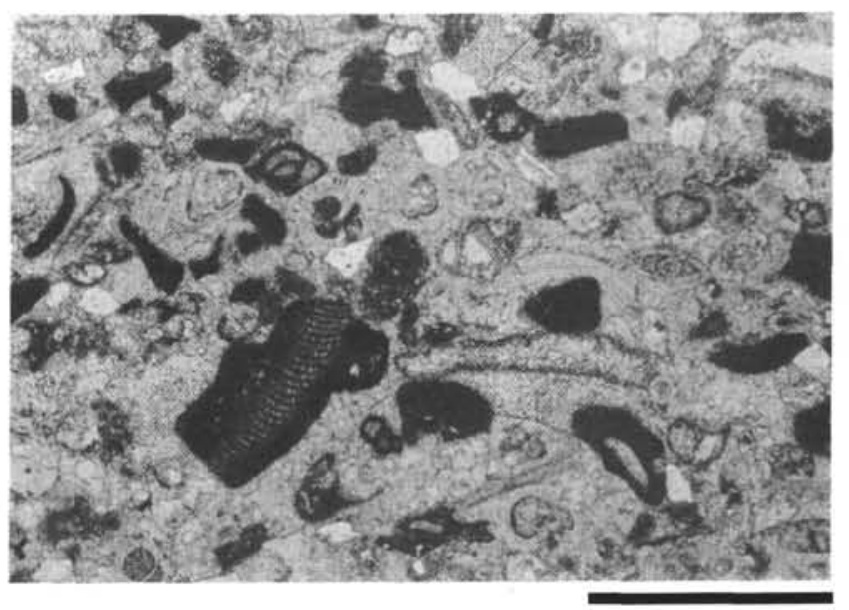

Figure 11. Typical microfacies of Panagra Marls (Langhian). Skeletal limestone containing fragments of shallow-water organisms (including calcite-filled molds of mollusks, echinoderms, benthic foraminifers and red algae), intraclasts, planktonic foraminifera, and some lithic fragments, quartz, feldspar and glauconite. This rock is tightly cemented by calcite. Sample LM 6188, sampled near Panagra, on the road from Panagra to Mirtou. Thinsection, scale bar $1 \mathrm{~mm}$. 

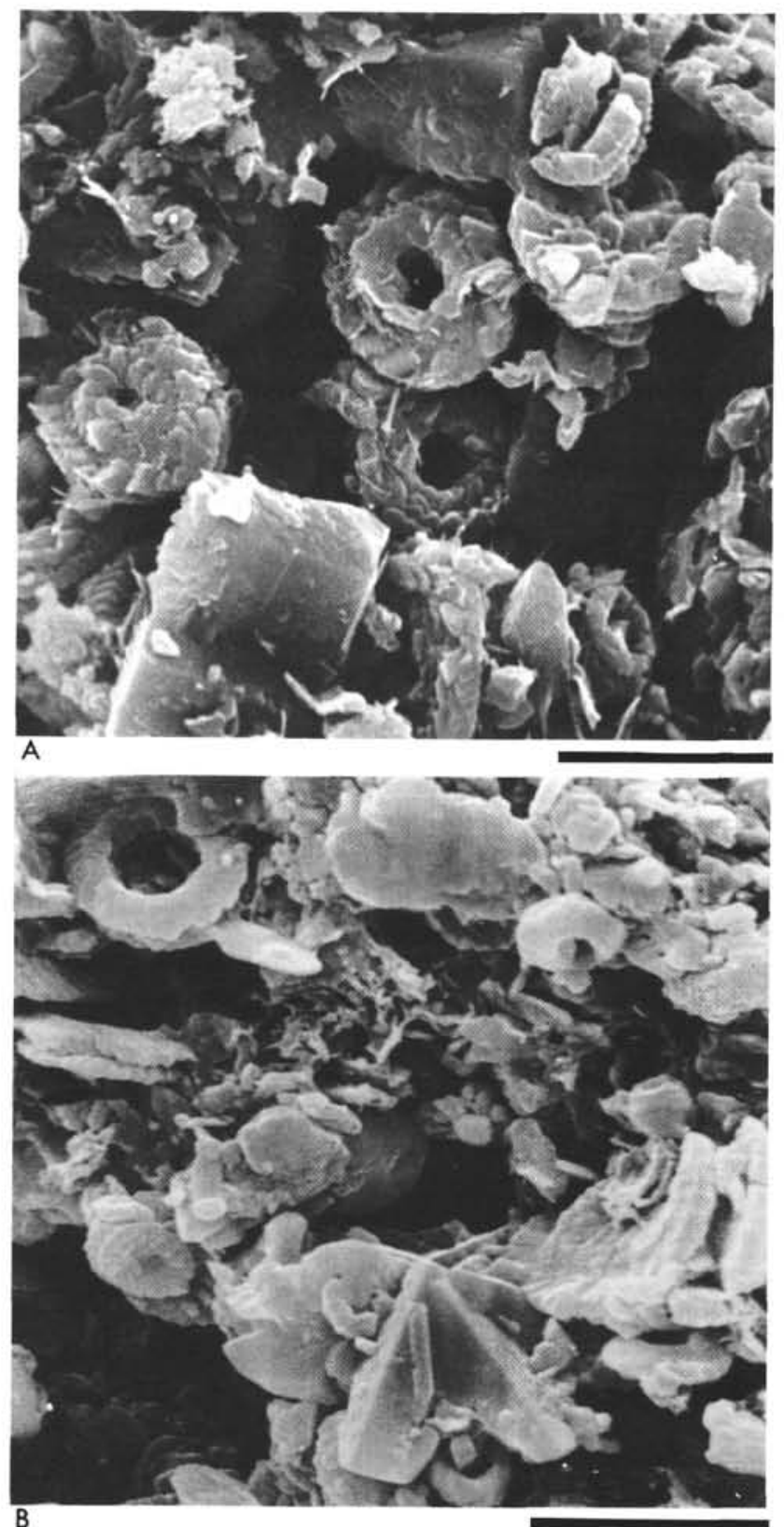

Figure 12. SEM-micrographs of pelagic sediments, Unit $X$, Site 375 and Panagra Marls. (A) Groundmass of foraminiferal limestone with coccoliths showing syntaxial overgrowth by rhombohedral carbonate, and neomorphic carbonate rhombs, presumably dolomite. Site 375, Unit X, Langhian, Sample 375-11-1, $125 \mathrm{~cm}$. (B) Groundmass of pelagic marly limestone showing coccoliths, discoasterids heavily overgrown by syntaxial calcite and flakes of clay minerals. Panagra Marls, Langhian. Sample Kyt 4, sampled between Agia Anna and Phyleri. Scale bars $5 \mu \mathrm{m}$.

Beside rarely occurring planktonic foraminifera, mainly shallow-water fossils such as nummulitids, rotalids, orbitoids, miliolids, Lepidocyclina spp., Miogypsinoides spp., Spiroclypeus, Amphistegina, Lithothamnium, bryozoans, crinoids, and bivalves occur (Figure 14). They are generally of Aquitanian age and occur as

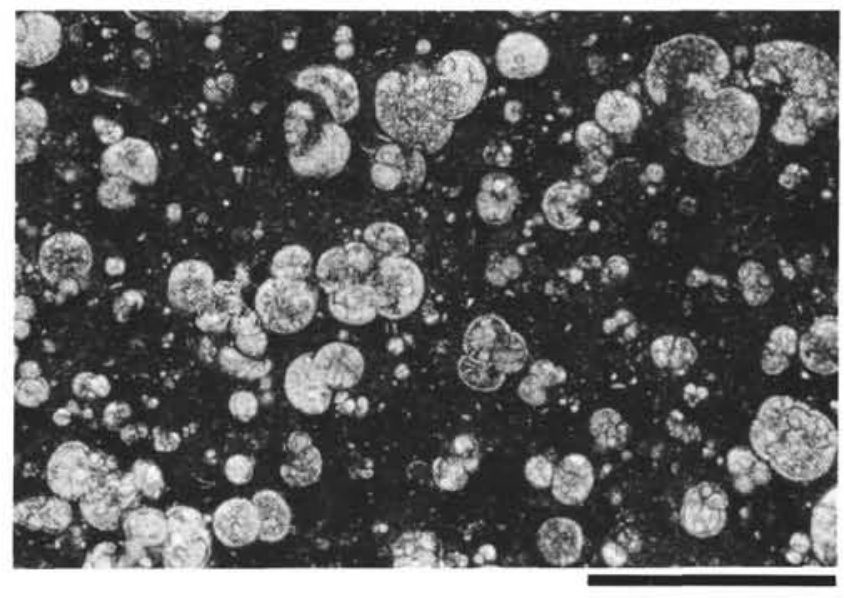

Figure 13. Marly limestone with abundant planktonic foraminifers. Unit XI, Site 375, Burdigalian, Sample 375-12, CC. Thin-section, scale bar $1 \mathrm{~mm}$.

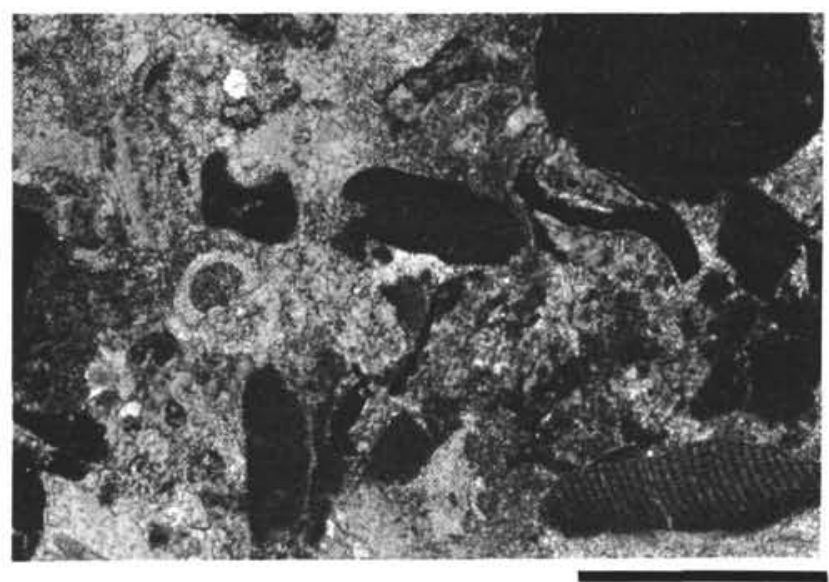

Figure 14. Typical microfacies of Flamoudhi Sandstone (Aquitanian-Burdigalian). Skeletal fine calcirudite to calcarenite, composed of closely packed fragments of red algae and various other shallow-water organisms with planktonic foraminifers; cemented by calcite. Sample ARD. 19, sampled west of Ardana. Thinsection, scale bar $1 \mathrm{~mm}$.

reworked and as penecontemporaneously displaced forms in the calcarenites intercalated between Aquitanian and Burdigalian marls.

\section{BIOSTRATIGRAPHY}

\section{Pliocene-Quaternary}

There are few possibilities of correlation between the pelagic marls of the Quaternary penetrated at Site 376 (0-39 m subbottom) and the Quaternary of Cyprus which is generally represented by calcarenites without or with very few planktonic foraminifera (continental to outer-shelf sediments). Some difficulties arose in the reconstruction of the stratigraphic succession in Core 5 and the upper part of Core 6 of Site. 376 (Bizon et al., this volume) where 5 meters of Pliocene nannofossil ooze are intercalated between sediments of 
the earliest Pleistocene (NN 19, Müller, this volume).

At Site 376, most of the Pliocene is strongly condensed but no hiatuses were recognized (Unit III). In Cores 5 and 6 five zones of planktonic foraminifera $(G$. inflata, G. obliquus extremus, S. subdehiscens, G. margaritae evoluta, G. margaritae) are contained in only 5.5 meters of brown to light gray nannofossil marl. Deformed gray marls (Unit IV) with an oligotypic assemblage of Rosalina sp. and Bolivina sp. are intercalated at the base of this sequence (Sphaeroidinellopsis Acme Zone). These indicate a restricted environment of probably shallow water (Posidonia - seaweeds, Blanc-Vernet, 1969). These marls, which are probably of late Miocene age, have been interpreted as a sedimentary slump emplaced during the earliest Pliocene. We believe that the close association of condensed sequences with submarine mass movement for the gray marls indicates a tectonically active zone.

A few additional observations concerning the early Pliocene foraminiferal associations are as follows. In Sample 1-1, $50 \mathrm{~cm}$, Site 375, some Protentella cf. nicobarensis were present. This species has been described recently from the lower Pliocene of Cap Nicobar in the Bay of Bengal, Globorotalia margaritae Zone (Srinivasan and Kennett, 1975). Their occurrence at Site 375 is the first record of this species in the Mediterranean. It was found more or less at the same stratigraphic level as in the Indian Ocean (Pl. 1, Fig. 7a,b). Pl. 7, Fig. 7b shows an enlarged view of the penultimate chamber with small subcircular pore pits.

On shore, the Pliocene marls are well known from earlier micropaleontological work (summarized in Baroz and Bizon, 1974). They are very rich in planktonic foraminifera. Benthonic foraminifera are generally well preserved and were described by Moore (1960) and others. In the Myrtou Marls, they make up over $20 \%$ of the population. They are more abundant in the upper part of the Pliocene formations and may comprise up to $60 \%$ and $70 \%$ in the sandy marls and sandstones of the Nicosia and Athalassa formations. At Site 376 , benthonic foraminifera are extremely rare in all the Pliocene sediments. This in itself is not an indication of great water depth. Recent observations by L. Blanc-Vernet (personal communication, 1976) show that in the Corsica channel the planktonic foraminifera make up $95 \%$ to $98 \%$ of the fauna in a water depth of $750 \mathrm{~m}$ to 800 meters. Predominance of pelagic species is not only a function of water depth but also of basin configuration and currents.

At both sites the Miocene/Pliocene boundary was not seen in the cores because of drilling disturbance; consequently we cannot assess the change in environments during this time.

\section{Unit V, Site 376}

The oliogotypic assemblage of Rosalina, Bolivina and the frequency of epipelagic foraminifera in the sedimentary slump intercalated in the lowermost Pliocene $(376-6-4,108 \mathrm{~cm})$ and in the uppermost part of Unit V (376, Core 7) indicates a shallow marine environment. Rosalina is known to live in the seaweeds of the present-day Mediterranean (Blanc-Vernet, 1969). Other samples of Core 7 were very poor in biota with only some fish remains (teeth and bones) and a few Turborotalita aff. clarkei.

Ammonia beccarii and Cyprideis assemblages are predominant in sediments of Cores 8 and 9. A few epipelagic planktonic foraminifera (Globigerina, Globigerinoides) and numerous Turborotalita aff. clarkei and $T$. cf. quinqueloba are present. In some samples, cysts of algae were also found.

From Core 10 to Sample 15 CC, Turborotalita aff. clarkei is present more or less throughout and sometimes is very abundant. In the turbiditic layers, reworked planktonic foraminifera occur frequently including species from the Maestrichtian up to the late Miocene (Globorotalia mediterranea).

In Core 13 Section 4, and Samples 13, CC and 14, $\mathrm{CC}$, the genus Cyprideis is frequently present and is associated with cysts of algae.

Turborotalita aff. clarkei (Rögl) was found in many samples of the dolomitic marls of Site 376 and is a very small species (less than $0.12 \mathrm{~mm}$ ), with spines and pores generally concentrated on the last whorl of the spire (Pl. 1, Fig. 1-5). The species looks very similar to specimens recorded by Fleisher (1974) from deep-sea cores of the Red Sea, and identified as Turborotalita "quinqueloba." They were recovered from immediately above the upper Miocene evaporites (Leg 23B, Site 225, Fleisher, 1974, pl. 2, fig. 4-6).

The cysts of algae belong to the species Pachysphera pelagica Ostenfeld. This planktonic algae (Pl. 1, Fig. 6) presently lives in the Atlantic Ocean, from 0 $\mathrm{m}$ to 50 meters water depth. Similar specimens were found in the Bay of Biscaye, in the English Channel and also in the Gulf of Mexico. Typically both marine and pelagic, these cysts are generally restricted to surface waters. They were also found in the dolomitic marls at Site 374, overlying the evaporites (Ionian Abyssal Plain, Cores 11, 13, 14).

What is the significance of the assemblages found directly above the evaporites at Site 376? Among the numerous ecological parameters - temperature, salinity, oxygen content, light penetration, availability of food, water depth, character of the substratum, $\mathrm{pH}$ general oceanic circulation - it is difficult to determine which one is responsible for the very poor assemblages at Site 376. From ecological studies on Recent foraminifera we know that very small variations of any one of these parameters may entirely modify the conditions of life and the general pattern of faunal distribution.

The influence of temperature may be relatively important as is shown by the occurrence of $T$. aff. clarkei. If $T$. aff. clarkei is not a juvenile form but is a species similar to $T$. quinqueloba, we may compare it also ecologically to this form. T. quinqueloba is generally considered as a cold to cool temperate water indicator (Reiss, 1974). However, although $T$. quinqueloba is common in Antarctic waters, it is also found in warmer waters. In Antarctic waters, it is associated with G. pachyderma (Herb, 1968), in warmer waters, with numerous other species. 
We believe that salinity played a major role in the depositional environments of Cores 13 and 14, as we found several euryhaline Cyprideis without associated Ammonia. The association includes also $T$. aff. clarkei and cysts of algae which could indicate a stratification of the water masses. We are uncertain whether these waters were hyper- or hyposaline, as lower and higher salinities have a similar influence on the biological environment.

The oxygen content was probably very low near the sea floor, and did not allow active benthonic life; this is confirmed by the total absence of burrowing in this unit.

Light penetration, food supply, $p \mathrm{H}$, and oceanic circulation were probably also important factors. We have, however, very few data which we can use to interpret the foraminiferal assemblages with respect to these parameters.

Few autochthonous benthonic species were found which confirms the restricted environment; however, the abundance of in situ Cyprideis and Ammonia indicates a water depth of 10-50 meters.

In summary, we conclude that the restricted environmental conditions reflect exceptional conditions of salinity, temperature, oxygen content, and water depth following the Messinian salinity crisis.

Two of us (G. Bizon and J. J. Bizon) think that the faunal assemblages, particularly those of Cores 8 and 9 , are shallow marine. In their view there are no data to prove that the epipelagic planktonic foraminifers are reworked as is suggested by Cita et al. (this volume). Cyprideis presently live in the Zoostera nana seaweeds of the "bassin d'Arcachon," an inlet of the Atlantic Ocean. In this area, Le Campion (1968) also found some living epipelagic foraminifers including the genera Globigerina, Globigerinoides, and Orbulina. In the opinion of G. and J. J. Bizon the data collected at Site 376 , including the presence of marine algae and of planktonic and benthonic foraminifers, disprove that a "Lac Mer" type of water-body, as defined by Gignoux (1960, p. 639), existed during the late Messinian in this part of the eastern Mediterranean.

On shore, no equivalent is known for the dolomitic marls of Unit V. In the Axylou and Alektora sections (southwestern Cyprus), a few samples from 10 meters of marls intercalated between the Miocene evaporites and the lower Pliocene with G. margaritae were investigated. Some Ammonia, Elphidium and ostracodes were found, indicating a marine outer-shelf environment.

\section{Unit VI - Site 375}

In some samples of sandy dolomitic marl intercalated in the evaporites at Site 375 (Samples 1-1, 126 $\mathrm{cm} ; 2-2,7 \mathrm{~cm}$; and 2-2, $30 \mathrm{~cm}$ ), a few Ammonia beccarii and Cyprideis were found together with some reworked material and perfectly preserved Globigerina and Globigerinoides. The reworked material of Sample $2-3,136 \mathrm{~cm}$, was carefully studied. The main faunal constituents are planktonic foraminifers, small benthionic foraminifers, and some large benthonic foraminifers. The oldest reworked planktonic foraminifers are of late Senonian age (Globotruncana stuarti, $G$. stuartiformis, G. fornicata, G. arca, Rugoglobigerina $\mathrm{sp}$.); the youngest include some species from the uppermost Miocene (Globorotalia mediterranea, $G$. humerosa, sinistral coiling). Paleocene (G. velascoensis), lower Eocene (G. rex), Oligocene (G. opima) and lower and middle Miocene forms were also found.

Among the larger benthonic foraminifers, the main constituents are Amphistegina, Operculina, Lepidocyclina, Miogypsina, and Miogypsinoides. Some perfectly preserved Lepidocyclina (Nephrolepidina) belong to the morgani group. The Miogypsina-Miogypsinoides assemblages look very primitive. Two specimens were identified as Miogypsina ex. interc. basraensis-formosensis from the Chattian.

Some Ammonia and Cyprideis debris were also found in this sample; their bad state of preservation, however, suggests that they are reworked. Shell fragments and echinoid debris were also found in addition to some lithic fragments of recrystallized limestone and of ophiolites.

The youngest forms of this heterogeneous assemblage belong to the Globorotalia mediterranea-Subzone of the late Miocene.

This mixed microfauna may be derived from Cyprus or from Turkey. Lepidocyclina morgani and Miogypsina basraensis-formosensis are known from the Flamoudhi Sandstones of northern Cyprus (Platymatis section) where they occur in redeposited calcarenites of the Globigerina ciperoensis zone. The older parts of the reworked fauna (globotruncanids) are similar to the late Senonian planktonic assemblages found in northern Cyprus (Malounda Formation). Obviously, as in other areas of the Mediterranean, pre-Messinian sequences were deeply eroded during deposition of the evaporites.

\section{Tortonian to Late Miocene-Globorotalia humerosa Zone-} Site 375, Cores 4 and 5

Core 4 came from about 60 meters below the base of the evaporites (Site 375/376 Report, this volume). The boundary between the evaporites and the late Miocene marls and arenites of Unit VII could not be studied. In the dolomitic marlstones of Unit VII only a few samples were fossiliferous. The others have a very poor fauna or are barren. Washed residues contained pyrite nodules, mica flakes, cysts of algae and some Orbulina, Globigerina and Globigerinoides obliquus incrusted by serpulids. Broken and thin-walled Orbulina are common (Pl. 3, Figs. 1, 3, 4).

Wall thickness of Orbulina varies from $7 \mu \mathrm{m}$ to 12 $\mu \mathrm{m}$. Lamellar growth takes place on the outer side of the primary organic membrane. Spines are destroyed. Holes on top of the spine bases are visible on Plate 3, Figures 1-6.

Globorotalia pseudomiocenica Bolli and Bermudez is relatively abundant in some intervals (Plate 2, Figures 5-11), but specimens are badly encrusted by sandy material. Some specimens are identified as Globorotalia menardii form 4 Tjalsma (in Zachariasse, 1975) and form 5 Tjalsma-Zachariasse, described from the late Miocene of Spain and Crete. 
In Globorotalia menardii form 4 (Plate 2, Figures 5, 8 ), the proximal end of the last three chambers joins the spiral suture at a right angle. In Globorotalia menardii form 5 (Figures 6, 7, 9-11), the intercameral sutures of the last three chambers make an obtuse angle with the spiral suture.

On Cyprus, in some samples of the pre-evaporitic Lapatza Formation of the Kythrea Group, planktonic foraminifera are abundant and perfectly preserved. Benthonic foraminifera are rare and represent only $1 \%$ of the total population. Big nodules of pyrite occur often in these sediments. Globorotalia pseudomiocenica is generally present and the populations are very similar to those of Cores 4 and 5 .

The wall surface of Orbulina universa d'Orbigny shows the spine bases with a counterclockwise spiral (Plate 3, Figure 6) as occurs in living specimens of the Indian Ocean (Bé et al., 1973).

In other late Miocene samples from the Mesaoria, restricted and dwarfed shallow-water microfaunas occur with $T$. multiloba, Bolivina dilatata, B. aff. dilatata, and $B$. dentellata. Such assemblages are well known on shore (Italy, Greece, Spain) where they characterize the Messinian. They were not found at Site 375 , but 60 meters was not recovered there and so they could be present.

\section{Tortonian-Globorotalia acostaensis Zone-Site 375, Cores 6 and 7}

The graded sandy layers of Core 6 were carefully studied. Heterogeneous assemblages were found, which include displaced foraminifers from the inner shelf (Borelis, miliolids), Ammonia beccarii and ostracodes. The planktonic foraminiferal assemblages are very poor and contain many reworked species from the late Cretaceous and the Paleogene. Wood fragments and gypsum are abundant. Orbulinas are characterized by their large size and very thin, often broken walls. Globigerinoides obliquus is the main constituent of these assemblages. In core 7 Globorotalia acostaensis is generally dextrally coiling. Some cysts of algae are present in Samples 7-5, $93 \mathrm{~cm}$, and 7-6, $95 \mathrm{~cm}$.

In the Tortonian stratotype section, G. acostaensis is right-coiling in the lower part of the $G$. acostaensis Zone (levels 4 to 6 of the Rio Mazzapiedi section). The assemblages in Core 7 are thus correlated to the lower part of the G. acostaensis Zone. The planktonic foraminiferal assemblages in the Mia Milea Formation, the equivalent of the Tortonian of Site 375 on Cyprus, are also generally very poor; reworked material is common. Orbulina is large and has a very thin wall. Benthonic foraminifera are usually present and include displaced outer-shelf species (Elphidium, Ammonia).

\section{Serravallian-Globorotalia mayeri Zone-Site 375, Cores 8, 9 (upper part)}

The upper part of Core 8, Sections 1 and 2, contain a fairly rich microfauna in which epipelagic species predominate. The genus Globorotalia was represented only by small $G$. scitula. The last occurrence of $G$. mayeri is in Core 8 , Section 3, but this could be faciescontrolled. Core 8 , Sections 5 and 6 , have planktonic foraminiferal assemblages very different in composition (Bizon et al., this volume): in Section 5, $26 \mathrm{~cm}, G$. obliquus predominates; In Section $6,36 \mathrm{~cm}$, the main species is $G$. dehiscens; In Sample 8, CC, the dominant species are $G$. altispira and G. subquadratus. While Sediments of Core 9, upper part, are similar in faunal content to the lower part of Core 8, with large $G$. altispira and $G$. dehiscens. Reworked material from the Late Cretaceous and the Eocene is usually present.

Globigerina druryi Akers with wedge-shaped chambers (Plate 2, Figures 12-14) was determined in some samples. The thick apertural rim (Plate 2, Figure 14) is nearly smooth and not pustulate as in the ancestral form Globigerina falconensis (Blow).

These assemblages are very similar to those of the lower part of the Trapeza Formation of the Kythrea Group. The lower part of the G. mayeri Zone is very rich in Globoquadrina. Numerous Globoquadrina are often found in sediments of the same age in the eastern Mediterranean. On Cyprus, benthonic foraminifera are generally common; they represent more than $20 \%$ of the total population and include Bulimina and Valvulinera. Reworked material is also present. The upper part of Core 8 records the initiation of a restricted environment. The same occurs in the middle and upper part of the Trapeza Formation where epipelagic foraminifers predominate. Large Orbulina sometimes have thin walls and spine bases (Plate 3, Figure 5) and large Globoquadrina are also present whereas keeled Globorotalia are generally absent.

\section{Langhian-Globorotalia fohsi peripheroronda-Praeorbulina glomerosa Zones-Site 375, Core 9, Lower Part, Cores 10, 11}

The last occurrence of Globorotalia fohsi peripheroronda is in Sample 9-6,90 cm. In this sample, some Globorotalia look very similar to G. fohsi peripheroacuta (Plate 2, Figures 1, 2). Globorotalia with five chambers in the last whorl and a lobate periphery usually have a poreless area near the periphery on the umbilical side. The wall is thickened on the first chambers, on the spiral side (Plate 2, Figures 3, 4a,b). Some Globorotalia from Site 372 had similar thickenings (Bizon et al., this volume).

Pink and white planktonic foraminifers in the turbiditic layers of Core 10 were size-sorted and were often crushed post-depositionally. Some pink and white crushed specimens also occur in sediments of Core 11 (P. glomerosa Zone). Protentella sp. occurs here as on Cyprus and the last occurrence of Cassigerinella is in Sample 11-1, $144 \mathrm{~cm}$.

The faunas of these intervals are similar in content and preservation to those of the Panagra Marls of the Kythrea Group. Benthonic foraminifera are present on Cyprus, but absent or very rare at Site 375 . This is consistent with the more distal turbiditic character of Unit X with respect to the Panagra Marls.

\section{Burdigalian-Globigerinita dissimilis-Globigerinoides altiaperturus Zone-Cores 12(?)-13}

Cores 12 and 13 had a very poor recovery and the sediments of Core 12 were barren. Sample 13-1, 132 
cm was examined more closely. The planktonic foraminiferal assemblage is comparable to the microfauna recorded in the Flamoudhi Sandstones of the Kythrea Group; the fossil preservation is also similar. In the Flamoudhi Sandstones, however, benthonic foraminifers are generally well represented and constitute $50 \%$ of the total population, whereas at Site 375 planktonic foraminifera are dominant and benthonic foraminifera are very rare. Some silty samples in Core 13 were barren; the same was found in most of the sandy layers of the Flamoudhi Formation.

From our investigations the biostratigraphic sequence recovered at Site 375 is more similar to the Kythrea Group of northern Cyprus, than to the Tertiary formations cropping out along the northern and southern margins of the Troodos. The white chalky sediments of the Troodos area which range from the Burdigalian to the late Miocene are generally characterized by an increased benthonic/planktonic ratio in contrast to the assemblages from northern Cyprus and those of Site 375. Benthonic foraminifera from the outer shelf, including Elphidium and Amphistegina, are present. In the upper Miocene, some dwarfed microfauna occur which indicate a relatively restricted shallow-water environment. Foraminifers from the innershelf (Borelis) are found in the Koronia Limestone of late Miocene age. In summary, the number of benthonic foraminifers strongly decreases from southern Cyprus to the north and from northern Cyprus further toward Site 375.

The faunal assemblages of the pre-evaporitic Miocene sediments penetrated at Site 375 are similar to those of the turbiditic Kythrea Group of northern Cyprus, but different from those of many other areas of the eastern Mediterranean.

Langhian and early Serravallian planktonic foraminiferal assemblages are characterized by large specimens. Pink forms and crushed specimens occur at Site 375 as in northern Cyprus.

Late Serravallian and Tortonian assemblages are more restricted. Most of the samples are barren. Reworked material and broken tests are common. Epipelagic species predominate, including large, thin-walled Orbulina, associated with $G$. obliquus, whereas keeled Globorotalia are absent in sediments of Site 375, Cores 6 and 7 and in most samples of Cores 4 and 5. The environment is clearly different from that at Site 372 , where, in the Serravallian to early Tortonian, keeled Globorotalia occur.

The significance of these environmental differences is difficult to evaluate. Observations made by Bé et al. (1973) on Orbulina universa d'Orbigny from the Indian Ocean have suggested that the diameter in Orbulina tests increases from high to low latitude. These authors also believe that the wall thickening of Orbulina is an adaptation to deeper habitats. The great abundance of thin-walled Orbulina in Cores 4 to 7 and in the middle and upper part of the Kythrea Group then indicates that the planktonic foraminifera usually came from the upper layers of the water masses. Conditions of stagnant bottom waters and oxygen deficiency are indicated by the abundance of organic matter in the sediments and the general scarcity in autochthonous benthonic fauna and burrowing organisms. Transport by turbidity currents was very important in the displacement of biota as confirmed by the sedimentary structures.

\section{CONCLUSIONS}

Although the stratigraphic documentation in cores (obtained by spot coring and often with poor recovery) is very incomplete and observations are of different scale (performed on $5 \mathrm{~cm}$ wide cores versus outcrop), lithologic and biostratigraphic correlation of the sections at Sites 375 and 376 with data from outcrops is more than sufficient to draw some important conclusions on the paleotectonic and paleogeographic history of the region.

\section{Pliocene-Pleistocene}

The present, relatively linear features of the Cyprus Arc do not correspond to the Miocene paleogeographic trends, but is cut obliquely through the facies belts as shown by the different pre-Messinian facies in the Troodos area and on the Florence Rise. The arcs are thus the result of young compressional movements and overthrusts towards the south in the Pentadaktylos Range and in the Troodos-Florence Rise belt. This is amply confirmed by seismic reflection data and by the seismicity of the area. On the seismic lines the Florence Rise appears as an elongated high, trending approximately west-northwest-east-southeast. It extends between subsident basins to the north (Antalya Basin) and to the south (Herodotus Abyssal Plain). The condensed Pliocene and Quaternary sequences at Site 376 show that the rise was sheltered from terrigenous influence by deeper basins. On the flanks of the rise, important halokinetic movements (Lort, 1972) disturb the Pliocene-Quaternary series; such movements could explain both local stratigraphic condensation and slumping as observed at Site 376 . Compared with the lower Pliocene of Site 376 the lower Pliocene of the Mesaoria Basin seems to have been deposited in a shallower and more oxygenated environment. During the late Pliocene and the Quaternary, Cyprus was uplifted and the Quaternary is continental except for the coastal areas where marine terraces with beach deposits exist. At times, there must have been a connection with the continent as large land mammals (Rhinoceros) are found in Tyrrhenian calcarenites of Cyprus. Possibly the Pentadaktylos-Misis thrust belt was emergent at times forming a land bridge between the continent and Cyprus.

The occurrence of Indic faunas raises the question of a possible connection with the Indian Ocean during Pliocene time. In this case a marine connection would have been reopened during the early Pliocene, after the Red Sea was closed off from the Indian Ocean during the late Miocene.

\section{Messinian}

The thinning of the evaporitic layers and the pinching out of the salt along the Florence Rise indicate that the rise was already in existence during the late Mio- 
cene. At places, northwest of Site 375 , a thinned salt layer overlays the ridge, but generally the distribution of the evaporites show that the main structural units already existed (Montadert et al., this volume). The very great thickness of the evaporites north $( \pm 1500 \mathrm{~m})$ and south $( \pm 3000 \mathrm{~m})$ of the rise may be a result of subsidence and/or progressive infilling of the previously existing basins.

On Cyprus lateral changes from basinal evaporites (including halite deposits, Gass, 1960; Pantazis, this volume) to marginal deposits, characterized by evaporites, reefoidal limestones and unconformities around the Troodos high, indicate that evaporite deposition occurred in a number of different environments and tectonic settings. Similar environmental changes are widely known in southern Turkey (Montadert et al., this volume) and elsewhere in the Mediterranean. However, as the resolution of the biostratigraphic zonation in the Messinian is not sufficiently refined, no detailed stratigraphic correlation between the different facies is possible.

\section{Pre-Messinian}

The very close correlation between the Kythrea Group of northern Cyprus and the pre-Messinian Neogene sediments at Site 375 leaves no doubt that both sequences were laid down in the same depositional basin. Generally, in the Kythrea Group, thicknesses of the individual members and the amount of terrigenous material decreases from east to west. This general trend is fully confirmed by the reduced thicknesses found for the individual units at Site 375 and the paleocurrent directions which indicate sediment transport in the same direction (Weiler, 1964, 1965). Proximal sedimentation in the Kythrea Group (early Oligocene, Aquitanian-Burdigalian, Tortonian) is related to offlap movements and rejuvenation of relief in the adjacent land masses. Additional sources of sediment were topographic highs with pelagic sedimentation. Their displaced pelagic sediments (troodos) form intercalations with other distal turbidites (particularly Panagra Marls).

The sediments recovered at Site 375 do not necessarily correspond to the axis of the Mesaoria Basin. Terrigenous sediments are widespread along the edges of the onshore Antalya Basin and some clastic deepwater sediments may come from other than easterly sources.

Generally the basin of the Kythrea deposits was relatively deep over the entire early Miocene up to the Tortonian. During the early and middle Miocene most of the basin received distal turbiditic and hemipelagic sediments; it received more proximal turbiditic sediments in the Tortonian. These sediments were laid down under conditions which were at times more oxidyzed (Panagra Marls), and at times semireducing (Unit IX, Site 375) or even stagnant. The oxygen deficiency is suggested by the abundance of organic matter and pyrite, sparse burrowing and poor benthonic assemblages (Unit VII, Site 375). Generally the benthonic assemblages are indicative of epibathyal or greater depths (Site 375/376 Report, this volume). The trace fossil assemblage (Zoophycos, Chondrites, Planolites) is that usually found in fine-grained sediments of relatively deep and quiet waters.

The oldest sediments recovered at Site 375, Unit XI, which consists of dark green-gray limestones and marlstones of early Miocene (Burdigalian) age have no exact counterpart in the Kythrea Group. They consist of cyclic alternation of distal turbiditic mudstones to marlstones and foraminiferal limestones. They are distinguished from the coeval upper Lefkara Formation by the presence of turbiditic marlstones. They are distinguished from the Flamoudhi Sandstones, occurring north of the Pentadaktylos Range by the absence of proximal turbidites and of redeposited shallow-water carbonates and older limestone fragments.

At Site 375 the acoustic basement was not reached, but by comparison with Cyprus, the thick sedimentary layers below Unit XI appear to correspond to the older series from Maestrichtian (?) to Oligocene. In northern Cyprus, the early Miocene grades downward into Oligocene deposits which in turn overlie with an unconformity the ancestral late Eocene Pentadaktylos Range. In the south, surrounding the Troodos high, Burdigalian strata onlap the older series.

The Neogene evolution, as determined by biostratigraphic or sedimentological evidence at Sites 375 and 376 , is similar to the general evolution of the northeastern Mediterranean. Open marine conditions prevailed from Burdigalian to Langhian-Serravallian times. This is the age of a large transgression on the Taurus area and more general transgressions on the other margins of the eastern Mediterranean, which resulted in deposition of large shelf deposits, including reefs.

Restricted conditions began during the Serravallian and increased during the Tortonian. There was a strong regression in the Antalya, Adana, Iskenderun regions, in southern Cyprus and even along the Levantine margin. The result of this regression and the accompanying increase in relief are the more proximal terrigenous sequences in the Tortonian.

From the Cretaceous to the present the area has been an active margin. This unstability is clearly reflected in the sedimentation of the entire Neogene.

\section{ACKNOWLEDGMENTS}

D. Bernoulli thanks the Swiss National Science Foundation for its support during this project (Grant 2.125-0.74). R. Guggenheim provided facilities at the SEM Laboratory at the Geological Institute of Basel University; Mrs. L. Luginbühl operated the microscope and assisted in editing the paper.

G. and J. J. Bizon thank Dr. P. F. Burollet who critically read their manuscript, Dr. Boisseau and Dr. Labour (Station biologique du bassin d'Arcachon, France) who gave them material from the Zoostera nana seaweeds, Dr. J. Taugourdeau who identified the cysts of algae, and Dr. W. J. Zachariasse who provided them with material containing $G$. menardii from Crete.

B. Biju-Duval and J. Letouzey are grateful to people of the French Institute of Petroleum with whom the work was done; they thank also Miss H. Lapierre, B. Ozer, Z. Mallal, and E. Oztümer for useful discussions of the subject. 


\section{REFERENCES}

Aubert, M. and Baroz, F., 1974. Structure profonde de la chaine du Pentadaktylos et de la Mésaoria (Chypre): Rev. Inst. Franç Pétrole, v. 29, p. 361-373.

Baroz, F., 1970. Observations nouvelles sur l'Eocène de la chaine de Kyrenia (Chypre): C. R. Acad. Sci. Paris, v. 270 , p. $1205-1208$.

Baroz, F., 1977. Etude géologique de l'ile de Chypre: Thèse d'Etat. Université de Nancy I.

Baroz, F. and Bizon, G. 1974. Le Néogène de la chaine de Pentadaktylos et de la partie Nord de la Mesaoria (Chypre). Etude stratigraphique et micropaléontologique: Rev. Inst. Franç Pétrole, v. 29, p. 327-358.

Baroz, F., Desmet, A., and Lapierre, H., 1975. Trois familles volcaniques préorogéniques à Chypre. Comparaison et discussion géotectonique: Trois Réunion Ann. Sci. Terre, Montpellier, p. 26.

1976. Les traits dominants de la géologie de Chypre: Soc. Géo. France Bull., Ser. 7, v. 18, p. 419-427.

Bate, M. A. D., 1904. Further note of the remains of Elephas cypriotes from a cave-deposit in Cyprus: Phil. Trans. Roy. Soc. London, Ser. B, v. 197, p. 347-360.

1906. The pigmy Hippopotamus of Cyprus: Geol. Mag., n. ser. Dec. V., v. 6, p. 241-245.

Bé, A. W. H., Harrison, S. M., and Lott, L., 1973. Orbulina universa d'Orbigny in the Indian Ocean. Micropaleontology, v. 19, p. 150-192.

Beltrandi, M. D. and Biro Ph., 1975. The geology and geophysics of the Iskenderun Basin, offshore Southern Turkey: Rap. Comm. Int. Mer Medit., v. 23, p. 31-38.

Berggren, W. A. and van Couvering, J., 1974. Late Neogene Chronostratigraphy, Biostratigraphy, Biochronology and Paleoclimatology: Woods Hole Oceanographic Inst., Contrib., v. 16, p. 1-215.

Bernoulli, D., 1971. Redeposited pelagic sediments in the Jurassic of the Central Mediterranean area: Ann. Inst. Geol. Publ. Hung., v. 54, p. 71-90.

Biju-Duval, B., 1974. Commentaires de la carte géologique et structurale des bassins tertiaires du domaine méditerranéen. Rev. Inst. Franç Pétrole, v. 29, p. 607-639.

Biju-Duval, B., Courrier, P., and Letouzey, J., 1974. Interprétation de la structure des Monts de Misis, Turquie (Chevauchement pliocène et masses allochtones mises en place au Miocène) et son extension en Méditerranée orientale: Deuxieme Réunion Ann. Sci. Terre, Nancy, p. 48.

Biju-Duval, B., Lapierre, H., and Letouzey, J., 1974. Le massif ophiolitique du Troodos (Chypre) est-il allochtone comme son prolongement en Turquie (Nappe de Kevan, Kizil Dag): Deuxieme Réunion Ann. Sci. Terre, Nancy, p. 46.

Biju-Duval, B., Letouzey, J., Montadert, L., Courrier, P., Mugniot, J. F., and Sancho, J., 1974. Geology of the Mediterranean Sea basins. In Drake, C. A. and Burk, C. L. (Eds.), The geology of continental margins: New York (Springer-Verlag), p. 695-721.

Bizon, G., Bizon, J. J., Aubert, J., and Oertli, J., 1972. Atlas des principaux foraminifères planctoniques $\mathrm{du}$ bassin méditerranéen-Oligocène à Quaternaire. Technip ed., p. 1-316.

Bizon, G., Biju-Duval, B., Letouzey, J., Monod, O., Poisson, A., Özer, B., and Öztümer, E., 1974. Nouvelles précisions stratigraphiques concernant les bassins tertiaires du Sud de la Turquie (Antalya, Mut, Adana): Rev. Inst. Franç Pétrole, v. 29, p. 305-324.

Blanc Vernet, L., 1969. Contribution à l'étude des foraminifêres de Méditerranée. Station marine d'Endoume, p. $1-251$.
Blumenthal, M. M., 1963. Le système structural du Taurus sud anatolien, Livre à la mémoire du Prof. Fallot: Mém. Soc. Géol. France, v. 2, p. 611-662.

Bouma, A. H., 1962. Sedimentology of some flysch deposits: a graphic approach to facies interpretation: Amsterdam, New York (Elsevier).

Brunn, J. H., Dumont, J. F., Graciansky, P. C. de, Gutnic, M., Juteau, T., Marcoux, J., Monod, O., and Poisson, A., 1971. Outline of the geology of the western Taurids, In Campbell, A.S., (Ed.) Geology and history of Turkey: Tripoli, p. 225-255.

Burollet, P. F. and Byramjee, R. S., 1974. Réflexions sur la tectonique globale. Exemples africains et méditerranéens: C. F. P. Notes et Mémoires 11, p. 71-120.

Dumont, J. F., Gutnic, M., Marcoux, J., Monod, O. and Poisson, A., 1972. te Trais des tourides occidentales (Turquie). Définition du Bassin Pamphyllien: un nouveau domaine à ophiolites à la marge externe de la chaine taurique: Z. Dtsch. Geol. Ges., v. 123, p. 385-409.

Dunham, R. J., 1962. Classification of carbonate rocks according to depositional texture: Am. Assoc. Petrol. Geol. Mem., v. 1, p. 108-120.

Fleisher, R. L., 1974. Preliminary report on late Neogene Red Sea foraminifera. Initial Reports of the Deep Sea Drilling Project, Volume 23: Washington (U. S. Government Printing Office), p. 985-1011.

Gass, I. G., 1960. The geology and mineral resources of the Dhali area: Mem. Geol. Surv. Dept. Cyprus, v. 4, p. 1-116.

Gass, I. G. and Cockbain, A. E., 1961. Notes on the occurrence of gypsum in Cyprus: Overseas Geol. Min. Res., v. 8, p. 279-287.

Gignoux, M., 1960. Géologie stratigraphique: Paris (Masson) p. $1-759$.

Herb, R., 1968. Recent planktonic foraminifera from sediments of the Drake passage, Southern Ocean: Eclog. Geol. Helv. v. 62 , p. $467-480$.

Hesse, R., 1975. Turbiditic and non-turbiditic mudstone of Cretaceous flysch sections of the East Alps and other basins: Sedimentology, v. 22, p. 387-416.

Kluyver, H. M., 1969. Report on a regional geological mapping in Paphos District: Geol. Surv. Cyprus Bull., no. 4 , p. $21-36$

Lapierre, H. and Rocci, G., 1976. Le volcanisme alcalin du Sud-Ouest de Chypre et le problème de l'ouverture des régions téthysiennes au Trias: Tectonophysics, v. 30, p. 299-314.

Le Campion, J., 1968. Foraminifères des principaux biotopes du bassin d'Arcachon et du proche océan. Bull. Cent. Etud. Rech. Sci. Biarritz, v. 7, p. 207-391.

Lort, J. M., 1972. The crustal structure of the eastern Mediterranean: Ph.D. Thesis, University of Cambridge.

Monod, O., Marcoux, J., Poisson, A., and Dumont, J. F., 1974. Le domaine d'Antalya, témoin de la fracturation de la plate-forme africaine au cours du Trias. Bull. Soc. Géol. France, v. 16, p. 116-127.

Montenat, C., Bizon, G., Carbonnel, G., Müller, C., and Reneville, P., in press. Continuité ou discontinuité de sédimentation marine mio-pliocène en Méditerranée occidentale. L'exemple du bassin de Vera (Espagne méridionale). Rev. Inst. Franç Pétrole., v. 31, p. 613-663.

Moore, T. A., 1960. The geology and mineral resources of the Astromeritis. Kormakiti area: Mem. Géol. Surv. Dept. Cyprus, v. 6.

Mulder, C., 1973. Tectonic framework and distribution of Miocene chemical sediments with emphasis on the Eastern Mediterranean. In Drooger, (Ed.), Messinian events in the Mediterranean: Amsterdam, p. 44-59. 
Ozer, B., Biju-Duval, B., Courrier, P. and Letouzey, J. 1974. Geology of Neogene basins of Antalya, Mut and Adana. In Second Petrol. Cong., Turkey, p. 57-84.

Reiss, Z., Halicz, E., and Perelis, L., 1974. Planktonic Foraminiferida from recent sediment in the Gulf of Elat: Israel J. Earth-Sci., v. 23, p. 69-105.

Ricou, L. E., Argyriadis, I. and Lefêvre, R., 1974. Proposition d'une origine interne pour les nappes d'Antalya et le massif d'Alanya (Taurides occidentales Turquie): Bull. Soc. Géol. France, v. 16, p. 107-11.

Ricou, L. E., Argyriadis, J., and Marcoux, J., 1975. L'axe calcaire du Taurus, un alignement de fenêtres araboafricaines sous les nappes radiolaritiques, ophiolitiques et métamorphiques: Bull. Soc. Géol. France, v. 17, p. 10241044.

Rigo de Righi, M. and Cortesini, A., 1964. Gravity tectonics in foothills structure belt of southeast Turkey. Am. Assoc. Petrol. Geol. Bull., v. 48, p. 1911-1937.

Schietecatte, J. P., 1971. Geology in the Misis Mountains. In Campbell, A. S. (Ed.), Geology and history of Turkey, Tripoli, p. 305-312.

Schmidt, G. C., 1961. Stratigraphic nomenclature of the Adana region petroleum district VII: Petrol. Admin. Publ. Bull. Ankara, no. 6, p. 47-62.
Strinivlsan, M. S. and Kennett, J. P., 1975. The status of Bolliella, Beella, Protentella and related planktonic foraminifera based on surface ultrastructure: J. Foram. Res., v. 5, p. 155-165.

Sungurlu, O., 1974. Geology of the northern part of petroleum district VI. In Second Petrol. Cong., Turkey. p. 85107.

Weiler, Y., 1964. Some remarks on the Kythrea Flysch: Ann. Rept. Geol. Surv. Cyprus, p. 53-56.

1965. The folded Kythrea Flysch in Cyprus. Unpublished Ph.D. thesis, the Hebrew University of Jerusalem.

1969. The Miocene Kythrea Flysch basin in Cyprus: Committee Mediterranean Neogene Stratigraphy Proc. IV Session, Bologna 1967, Giorn. Geol., v. 35, p. 213-229.

1970. Mode of occurrence of pelites in the Kythrea Flysch basin (Cyprus): J. Sediment. Petrol., v. 40, p. 12551261.

Zachariasse, W. J., 1975. Planktonic foraminiferal biostratigraphy of the late Neogene of Crete (Greece): Utrecht Micropal. Bull. II, p. 1-171. 


\section{PLATE 1}

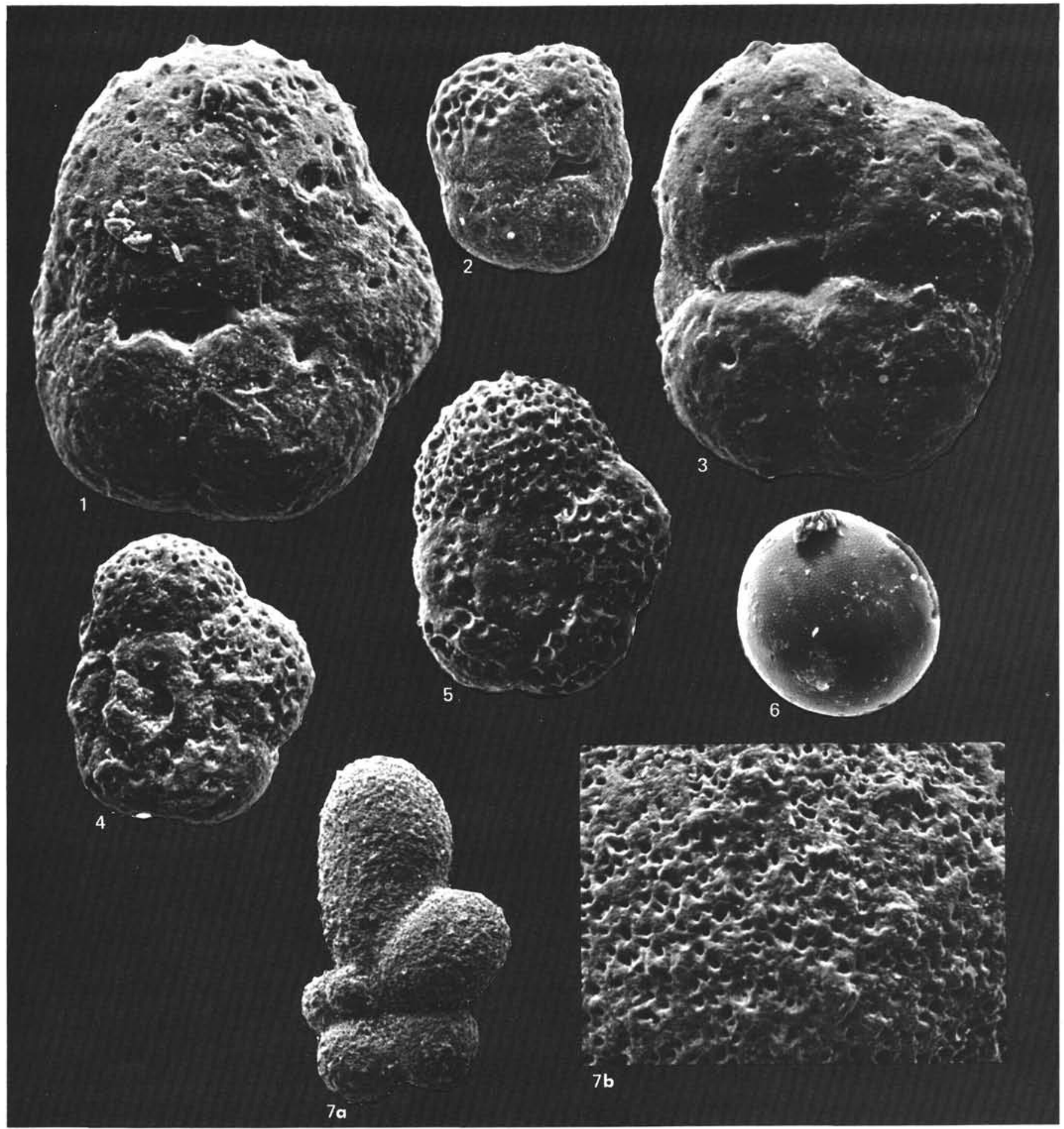

Figures 1, 3: $800 \times ; 2,4,5: 500 \times ; 6: 300 \times ; 7 a: 150 \times ; 7 b: 1000 \times$.

Figures 1-5 Turborotalita aff. clarkei (Rogl) - Site 376. 1, 2. Sample 7, CC. 3, 4. Sample 15-3, 130 cm; 5. SamFigure $6 \quad$ Pachysphaera pelagica (Ostenfeld) - Site 376, Core 9-4, $115 \mathrm{~cm}$.

Figures 7a, b Protentella $\mathrm{cf}$. nicobarensis (Srinivasan and Kennett) 7b Enlarged view of penultimate chamber Site 375 , Core 1-1, $50 \mathrm{~cm}$. 


\section{PLATE 2}

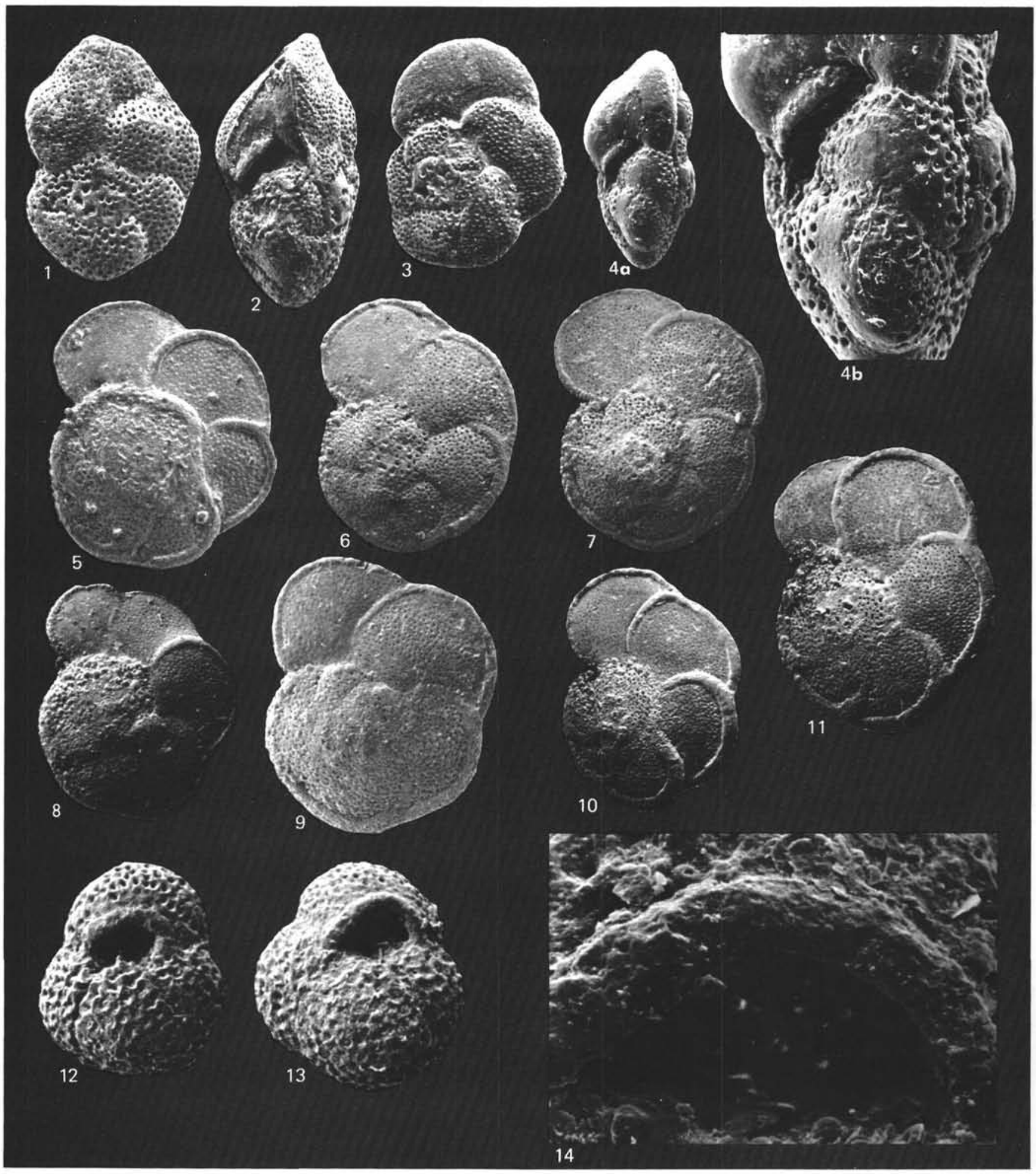

Figures 1-4a: $120 \times ; 4 \mathrm{~b}: 500 \times ; 5-11: 100 \times ; 12,13: 150 \times ; 14: 1000 \times$.

Figures 1,2 Globorotalia aff. fohsi peripheroacuta (Blow and Banner). Site 375, Sample 9-6, $98 \mathrm{~cm}$.

Figures 3,4 Globorotalia sp. Site 375, Sample 9-6, $98 \mathrm{~cm}$.

Figures 5-11 Globorotalia pseudomiocenica (Bolli and Bermudez). Site 375, Core 4-1, $156 \mathrm{~cm}$.

Figures 12-14 Globigerina druryi Akers. Site 375, Sample 9-3, $8 \mathrm{~cm}$. Fig. 14: enlarged view of apertural rim. 
PLATE 3

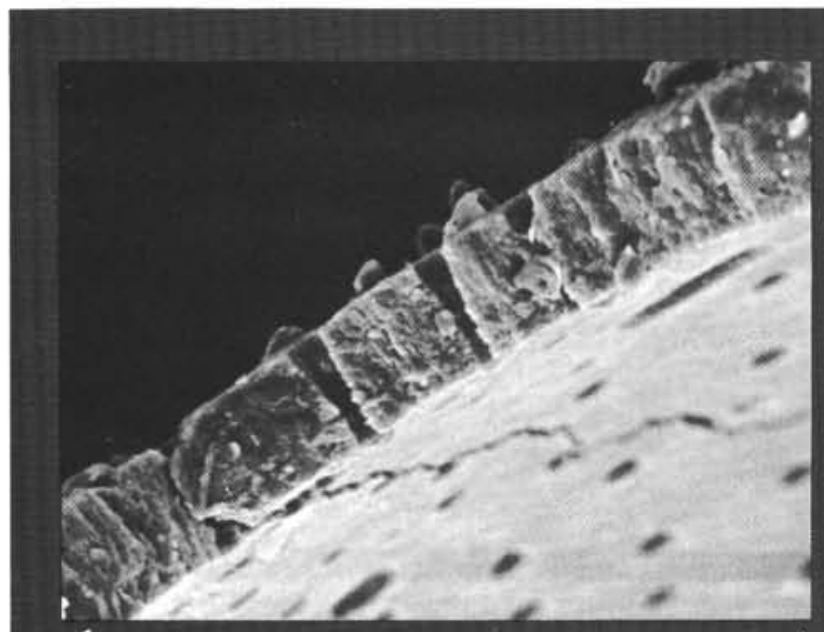

1
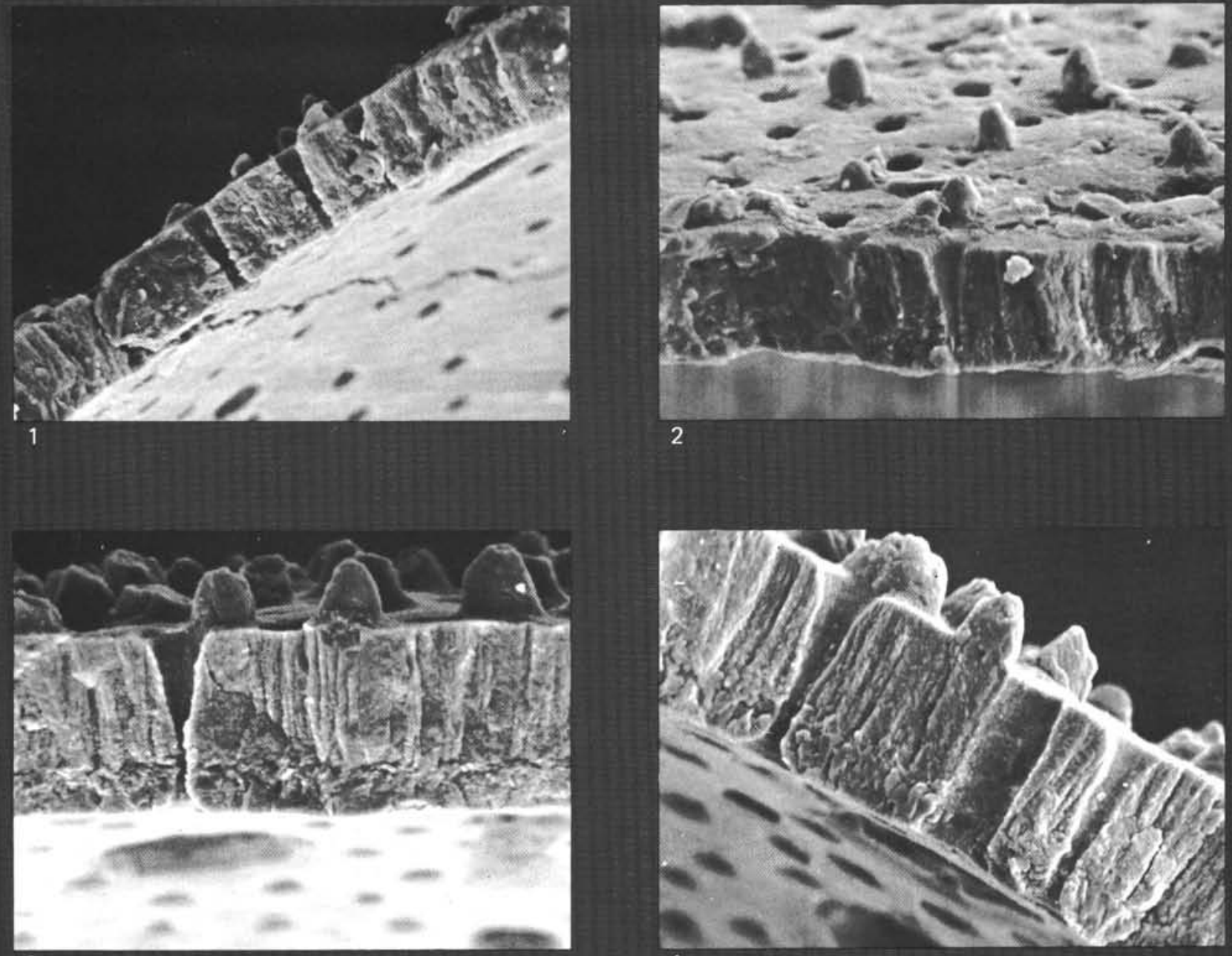

3

4

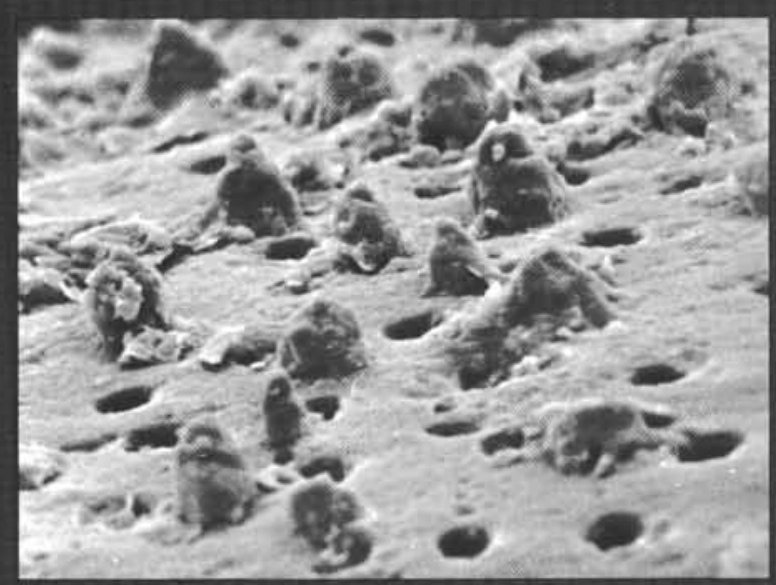

5

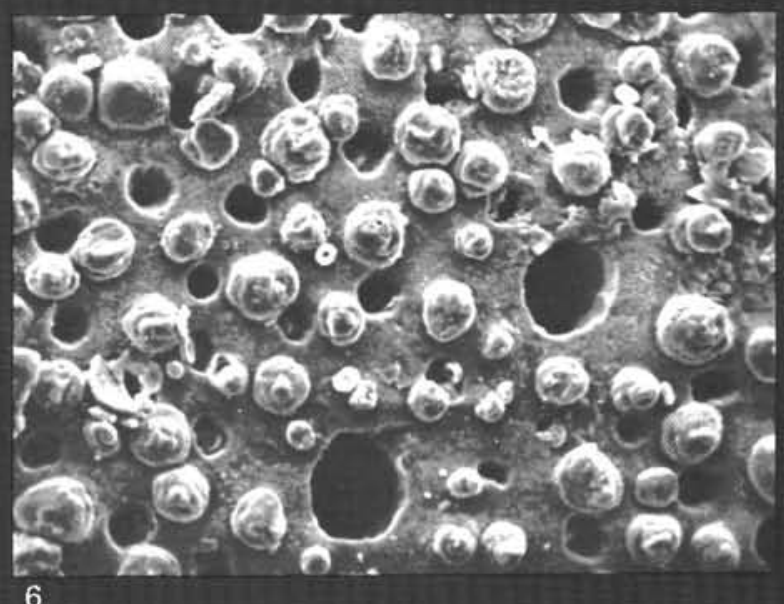

Figures 1-5: $2200 \times$; 6: $1200 \times$.

Figures 1-4 Details of the wall stucture in specimens of Orbulina universa (d'Orbigny).

1, 3, 4. Site 375, Sample 5, CC.

2. Cyprus Island, Trapeza Marls.

Figures 5, 6 Details of the wall structure in specimens of Orbulina universa (d'Orbigny).
5. Trapeza Marls.
6. Lapatza Formation Cyprus. 